\title{
Closing the Gaps in Our Knowledge of the Hydrological Cycle over Land: Conceptual Problems
}

\author{
William A. Lahoz • Gabriëlle J. M. De Lannoy
}

Received: 9 October 2012/Accepted: 25 January 2013/Published online: 15 March 2013

(C) The Author(s) 2013. This article is published with open access at Springerlink.com

\begin{abstract}
This paper reviews the conceptual problems limiting our current knowledge of the hydrological cycle over land. We start from the premise that to understand the hydrological cycle we need to make observations and develop dynamic models that encapsulate our understanding. Yet, neither the observations nor the models could give a complete picture of the hydrological cycle. Data assimilation combines observational and model information and adds value to both the model and the observations, yielding increasingly consistent and complete estimates of hydrological components. In this review paper we provide a historical perspective of conceptual problems and discuss state-of-theart hydrological observing, modelling and data assimilation systems.
\end{abstract}

Keywords Hydrological cycle · Earth observation · Land surface models · Data assimilation

\section{Introduction}

The water stored on land is a key variable controlling numerous processes and feedback loops within the climate system (see, e.g., Dirmeyer 2000; Koster et al. 2004a, b; Seneviratne et al. 2010). It constrains plant transpiration and photosynthesis and thus is of major relevance for the Earth's water and energy cycles and impacts the exchanges of trace gases on land, including carbon dioxide. Figure 1, from IPCC (2007), provides an overview of the main terrestrial components and exchanges within the climate system. This shows the complexity of land processes and feedbacks, to a large extent owing to the high spatial

W. A. Lahoz ( $\square)$

NILU, Instituttveien 18, PO Box 100, 2027 Kjeller, Norway

e-mail:wal@nilu.no

W. A. Lahoz

Météo-France, CNRM/GMGEC/CARMA, 42 avenue Gaspard Coriolis, 31100 Toulouse, France

G. J. M. De Lannoy

Global Modeling and Assimilation Office (Code 610.1), NASA/GSFC, Greenbelt, MD, USA

e-mail: Gabrielle.Delannoy@nasa.gov 


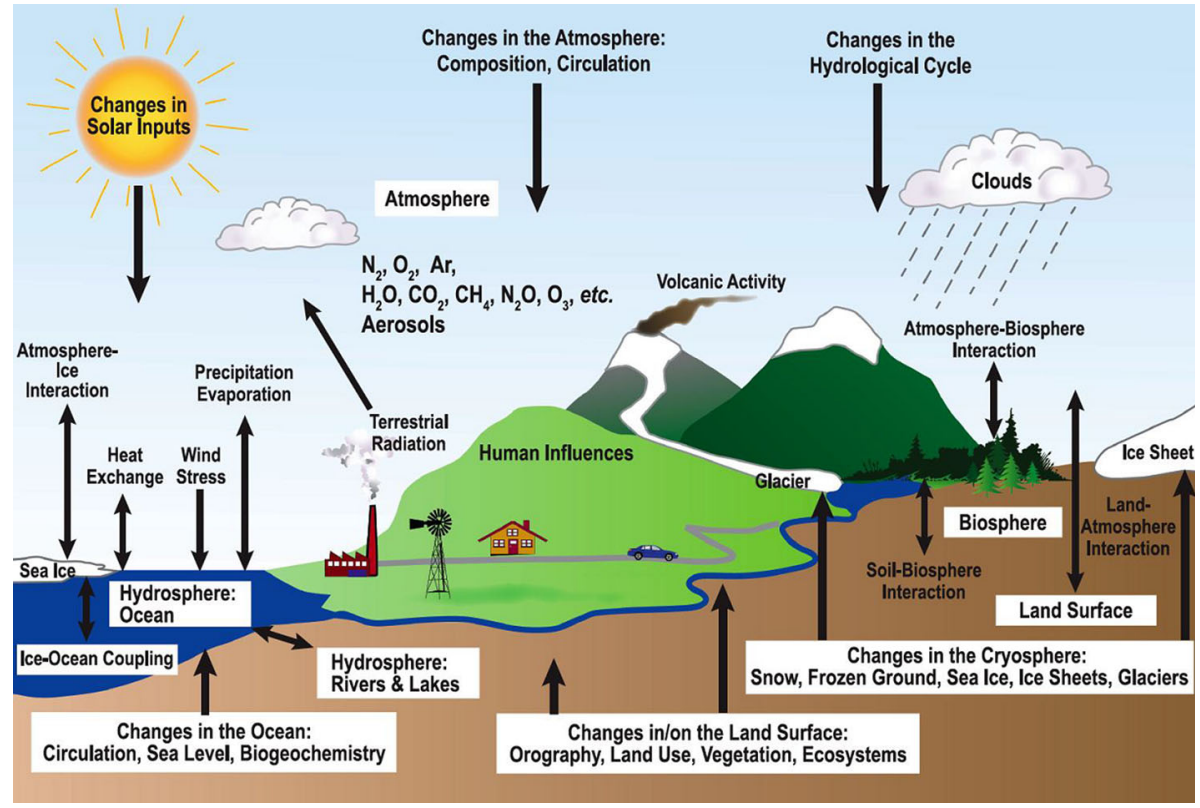

Fig. 1 Global climate system. Figure from IPCC (2007)

variability in soils, vegetation and topography (ranging from metres to kilometres). Processes affecting the amount of water stored on land, for example, precipitation and radiation, have spatial scales of kilometres (e.g., associated with weather fronts) and have high temporal variability (hours).

The amount of water stored in the unsaturated soil zone is generally referred to as soil moisture, although the exact definition can vary depending on the context. Soil moisture is one of the key geophysical variables for understanding the Earth's hydrological cycle. It is classed as an essential climate variable of the Global Climate Observing System (GCOS) (GCOS-107, 2006).

Soil moisture determines the partitioning of incoming water into infiltration and run-off. It directly affects plant growth and other organic processes and thus connects the water cycle to the carbon cycle. Run-off and base flow from the soil profile determine river flows and flooding, which connects hydrology with hydraulics. Soil moisture also has a significant impact on the partitioning of water and heat fluxes (latent and sensible heat), thereby connecting the hydrological (i.e. water) cycle with the energy cycle.

Soil moisture is a source of water for the atmosphere through evapotranspiration from land. Evapotranspiration is a major component of the continental water cycle, as it returns as much as $60 \%$ of the whole land precipitation back to the atmosphere (e.g., Oki and Kanae 2006). Furthermore, evapotranspiration is also an important energy flux (Trenberth et al. 2009) and is connected to the surface skin and soil temperature, which make up other important state variables of the land surface system. Together, soil moisture, temperature and their impacts on the water, energy and carbon cycle play a major role in climatechange projections (IPCC 2007; Seneviratne et al. 2010). Snow on land is another important variable affecting the global energy and water budgets, because of its high albedo, low thermal conductivity, considerable spatial and temporal variation and mediumterm capacity for water storage. 
Quantifying the land state and fluxes and understanding soil moisture-temperature and soil moisture-precipitation couplings allow a better representation of hydrological processes in climate models and significantly help to reduce uncertainties in future climate scenarios, in particular regarding changes in climate variability and extreme events, and ecosystem/agricultural impacts (Seneviratne et al. 2010). This understanding is also crucially important for improving short-range numerical weather prediction (NWP) capabilities, in particularly regarding prediction of convective precipitation (Sherwood 1999; Adams et al. 2011, and references therein).

Hydrological observations are prone to errors and are discrete in space and time with the result that the information provided by these observations has gaps. Figure 2 shows an example of gaps in satellite observations. It is desirable to fill gaps in the observed information using additional information and computational techniques. Algorithms or models to fill in information gaps should organize, summarize and propagate the information from observations in an objective and consistent way. A simple approach such as linear interpolation could be a reasonably accurate "model", when observations are dense enough. However, linear interpolation may not be consistent with our advanced understanding of how the land surface behaves. A more realistic approach would be to fill in the gaps using a land surface model (LSM). While observations give an instantaneous view of the land surface, LSMs provide continuous estimates, based on physical laws that are derived from historical observations. These models are not perfect, and gaps in their structure, parametrization or initialization can be filled in with observations.

3 August 2012

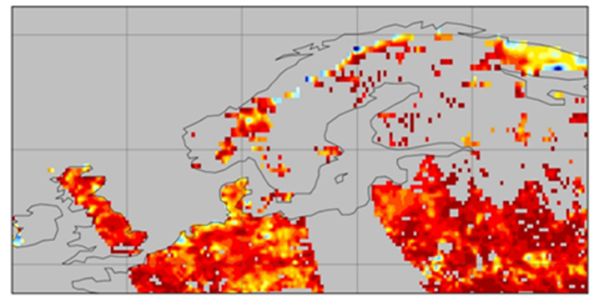

17 August 2012

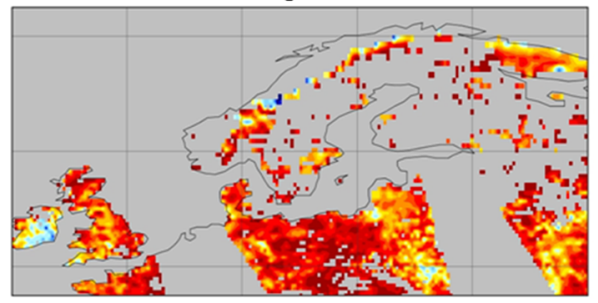

10 August 2012

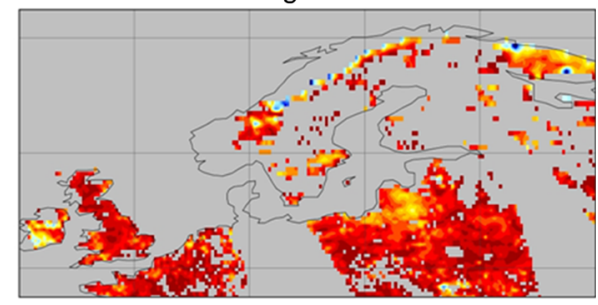

25 August 2012

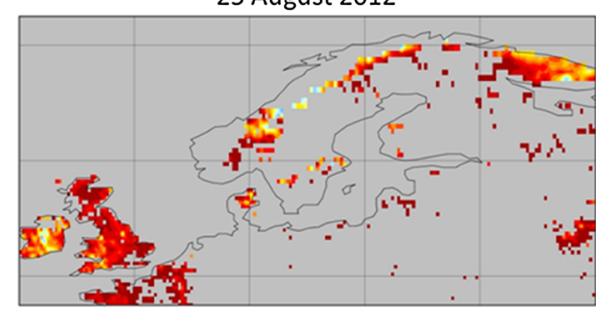

Retrieved soil moisture value (m3.m-3)

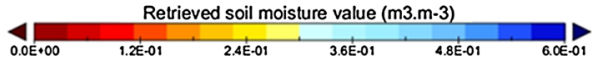

Fig. 2 Plot representing retrieved soil moisture data from the Soil Moisture Ocean Salinity (SMOS, Kerr et al. 2010) mission for August 3, 2012 (top left panel), August 10, 2012 (top right panel), August 17, 2012 (bottom left panel), and August 25, 2012 (bottom right panel), based on the observational geometry from ascending orbits from SMOS (units of $\mathrm{m}^{3} \mathrm{~m}^{-3}$ ). Blue denotes relatively wet values; red denotes relatively dry values. The uncoloured (i.e. grey) areas over land represent gaps between the satellite orbits. Noteworthy are the sparse SMOS observations over Scandinavia, where retrievals from remotely sensed observations are particularly difficult, when the land is covered with snow, ice, forest, water bodies or rocks 
Data assimilation (Kalnay 2003) provides an intelligent method to fill in the observational gaps using a model or to steer models using observations. By intelligent, it is meant an "objective" way which makes use of quantitative concepts (e.g., mathematical) for combining imperfect information. By combining observational and model information, data assimilation can be used to test the self-consistency and error characteristics of this information (Talagrand 2010b).

In this paper we focus on off-line land data assimilation, where the LSM is uncoupled from an atmospheric model. By using an uncoupled LSM, it can be forced with more observation-based forcings, rather than often inaccurate atmospheric analyses, and less computational resources are needed. The uncoupled approach can be regarded as a first step towards the land data assimilation goal of coupling an LSM to an atmospheric model to improve predictions at weather, seasonal and climate timescales (Palmer et al. 2008).

In this paper we discuss observations (Sect. 2), models (Sect. 3) and data assimilation methods (Sect. 4) used in the studies of the hydrological cycle and provide illustrative examples, with a focus on soil moisture. We pay special attention to the conceptual problems and key challenges associated with making use of observational and model information of the land surface in data assimilation systems (Sect. 5). We finish by providing conclusions (Sect. 6).

\section{Observations of the Hydrological Cycle}

Observations of the hydrological cycle are commonly divided into conventional observations (e.g., in situ ground-based measurements such as screen-level relative humidity) and remotely sensed observations (e.g., satellite or aircraft microwave observations). These data sets are complementary: conventional observations have relatively high spatio-temporal resolution (order metres and minutes) but only have local coverage, so have poor representativity for a large area; satellite observations have relatively low spatio-temporal resolution but have global coverage, so have good representativity for a large area. In situ observations are typically used as ground truth for calibration and validation of remote sensing products, and model and assimilation results.

Table 1 gives an overview of satellite sensors and missions that contribute to our current understanding of the hydrological cycle or may potentially contribute to this understanding in the near future. Depending on the observed wavelengths, the orbit altitude and design details, there are large differences in horizontal, vertical and temporal resolution of each observation type. For example, satellite-based observations of soil moisture are made using passive and active microwave instruments. The horizontal resolution of these sensors ranges from 50 to $10 \mathrm{~km}$; the temporal resolution is about one observation every 2-3 days, depending on the location on Earth. These instruments typically penetrate the first few millimetres to centimetres of the soil: a few millimetres for the $X$-band $(8-12 \mathrm{GHz}$, e.g., Advanced Microwave Sounding Radiometer for EOS, AMSR-E; Njoku and Chan 2006); $\sim 1 \mathrm{~cm}$ for the $C$-band (4-8 GHz, e.g., AMSR-E; Advanced SCATterometer, ASCAT; Bartalis et al. 2007); and $\sim 5 \mathrm{~cm}$ for the L-band (1-2 GHz, e.g., Soil Moisture Ocean Salinity, SMOS; Kerr et al. 2010). An immediate conceptual problem is to estimate soil moisture of actual interest in the root zone $(1 \mathrm{~m})$ at a finer resolution. For this, observational information needs to be transferred from the surface layer to the root zone (e.g., Calvet et al. 1998; Sabater et al. 2007; De Lannoy et al. 2007a; Draper et al. 2012) and downscaled from the coarse scale to finer scales (Reichle et al. 2001a; Pan et al. 2009; 
Table 1 Characteristics of hydrological observations potentially available within the next decade (see "Appendix" for details of sensor acronyms)

\begin{tabular}{|c|c|c|c|c|c|}
\hline $\begin{array}{l}\text { Hydrological } \\
\text { quantity }\end{array}$ & $\begin{array}{l}\text { Remote } \\
\text { sensing } \\
\text { technique }\end{array}$ & Timescale & $\begin{array}{l}\text { Spatial } \\
\text { scale }\end{array}$ & Accuracy considerations & $\begin{array}{l}\text { Examples of } \\
\text { sensors }\end{array}$ \\
\hline \multirow[t]{5}{*}{ Precipitation } & \multirow{3}{*}{$\begin{array}{l}\text { Thermal } \\
\text { infrared }\end{array}$} & Hourly & $4 \mathrm{~km}$ & \multirow{3}{*}{$\begin{array}{l}\text { Tropical convective clouds } \\
\text { only }\end{array}$} & \multirow{3}{*}{$\begin{array}{l}\text { GOES, MODIS, } \\
\text { AVHRR, } \\
\text { Landsat, ASTER }\end{array}$} \\
\hline & & 1 day & $1 \mathrm{~km}$ & & \\
\hline & & 15 days & $60 \mathrm{~m}$ & & \\
\hline & $\begin{array}{l}\text { Passive } \\
\text { microwave }\end{array}$ & $3 \mathrm{~h}$ & $10 \mathrm{~km}$ & Land calibration problems & $\begin{array}{l}\text { TRMM, SSMI, } \\
\text { AMSR-E, GPM }\end{array}$ \\
\hline & $\begin{array}{l}\text { Active } \\
\text { microwave }\end{array}$ & Daily & $10 \mathrm{~m}$ & Land calibration problems & TRMM, GPM \\
\hline \multirow[t]{3}{*}{$\begin{array}{l}\text { Surface soil } \\
\text { moisture }\end{array}$} & $\begin{array}{l}\text { Passive } \\
\text { microwave }\end{array}$ & 1-3 days & $25-50 \mathrm{~km}$ & $\begin{array}{l}\text { Limited to sparse } \\
\text { vegetation, low } \\
\text { topographic relief }\end{array}$ & $\begin{array}{l}\text { AMSR-E, SMOS, } \\
\text { Aquarius, SMAP }\end{array}$ \\
\hline & \multirow{2}{*}{$\begin{array}{l}\text { Active } \\
\text { microwave }\end{array}$} & 3 days & $3 \mathrm{~km}$ & \multirow{2}{*}{$\begin{array}{l}\text { Significant noise from } \\
\text { vegetation and roughness }\end{array}$} & \multirow{2}{*}{$\begin{array}{l}\text { ERS, JERS, } \\
\text { Radarsat, } \\
\text { ASCAT }\end{array}$} \\
\hline & & 30 days & $10 \mathrm{~m}$ & & \\
\hline \multirow{3}{*}{$\begin{array}{l}\text { Surface skin } \\
\text { temperature }\end{array}$} & \multirow{3}{*}{$\begin{array}{l}\text { Thermal } \\
\text { infrared }\end{array}$} & $1 \mathrm{~h}$ & $4 \mathrm{~km}$ & \multirow{3}{*}{$\begin{array}{l}\text { Soil/vegetation average, } \\
\text { cloud contamination }\end{array}$} & \multirow{3}{*}{$\begin{array}{l}\text { GOES, MODIS, } \\
\text { AVHRR, } \\
\text { Landsat, ASTER }\end{array}$} \\
\hline & & 1 day & $1 \mathrm{~km}$ & & \\
\hline & & 15 days & $60 \mathrm{~m}$ & & \\
\hline \multirow[t]{3}{*}{ Snow cover } & \multirow{3}{*}{$\begin{array}{l}\text { Visible/ } \\
\text { thermal } \\
\text { infrared }\end{array}$} & $1 \mathrm{~h}$ & $4 \mathrm{~km}$ & \multirow{3}{*}{$\begin{array}{l}\text { Cloud contamination, } \\
\text { vegetation masking, } \\
\text { bright soil problems }\end{array}$} & \multirow{3}{*}{$\begin{array}{l}\text { GOES, MODIS, } \\
\text { AVHRR, } \\
\text { Landsat, ASTER }\end{array}$} \\
\hline & & 1 day & $\begin{array}{c}500 \mathrm{~m}- \\
1 \mathrm{~km}\end{array}$ & & \\
\hline & & 15 days & $30-60 \mathrm{~m}$ & & \\
\hline \multirow{2}{*}{$\begin{array}{l}\text { Snow water } \\
\text { equivalent } \\
\text { (SWE) }\end{array}$} & $\begin{array}{l}\text { Passive } \\
\text { microwave }\end{array}$ & 1-3 days & $10 \mathrm{~km}$ & Limited depth penetration & AMSR-E \\
\hline & $\begin{array}{l}\text { Active } \\
\text { microwave }\end{array}$ & 30 days & $100 \mathrm{~m}$ & Limited spatial coverage & $\begin{array}{l}\text { SnoSat, SCLP, } \\
\text { Cryosat-2, } \\
\text { CoreH2O }\end{array}$ \\
\hline \multirow[t]{2}{*}{$\begin{array}{l}\text { Water level/ } \\
\text { velocity }\end{array}$} & Laser & 10 days & $100 \mathrm{~m}$ & Cloud penetration problems & $\begin{array}{l}\text { ICESAT, } \\
\text { ICESAT2, } \\
\text { SWOT, } \\
\text { DESDynl }\end{array}$ \\
\hline & Radar & 30 days & $1 \mathrm{~km}$ & Limited to large rivers & $\begin{array}{l}\text { TOPEX/ } \\
\text { POSEIDON }\end{array}$ \\
\hline $\begin{array}{l}\text { Total water } \\
\text { storage } \\
\text { changes }\end{array}$ & $\begin{array}{l}\text { Gravity } \\
\text { changes }\end{array}$ & 30 days & $1,000 \mathrm{~km}$ & Bulk water storage change & $\begin{array}{l}\text { GRACE, GOCS, } \\
\text { GRACEII }\end{array}$ \\
\hline \multirow[t]{3}{*}{ Evaporation } & & $1 \mathrm{~h}$ & $4 \mathrm{~km}$ & \multirow[t]{3}{*}{ Significant assumptions } & \multirow{3}{*}{$\begin{array}{l}\text { GOES, MODIS, } \\
\text { AVHRR, } \\
\text { Landsat, ASTER }\end{array}$} \\
\hline & & 1 day & $1 \mathrm{~km}$ & & \\
\hline & & 15 days & $60 \mathrm{~m}$ & & \\
\hline
\end{tabular}

Table updated from Houser et al. (2010)

De Lannoy et al. 2010; Sahoo et al. 2013) typically using a land surface model (discussed in Sect. 3) and/or land data assimilation (discussed in Sect. 4).

With the design of new sensors, one aims to gain resolution, increase the sensitivity to the variables of interest and reduce instrument errors (USGEO 2010). Examples of new missions for soil moisture observations are the SMOS and SMAP (Soil Moisture Active and Passive) missions, both using L-band sensors and designed with a target uncertainty 
lower than that of earlier missions, like AMSR-E and ASCAT. In November 2009, the ESA Earth Explorer mission SMOS was launched followed by another L-band mission, NASA/CONAE Aquarius (Le Vine et al. 2006), in June 2011. Aquarius measures various elements of the hydrological cycle, and its coarse resolution makes it less attractive for soil moisture estimation. The NASA mission SMAP is focused on soil moisture and freezethaw detection and is scheduled for launch in 2014 (Entekhabi et al. 2010a). To illustrate the importance of soil moisture information, Table 2 identifies key benefits from satellite soil moisture measurements.

A special issue on soil moisture from the SMOS mission has recently appeared in the IEEE Transactions on Geoscience and Remote Sensing (Kerr et al. 2012a). The papers in this special issue describe the SMOS mission (Mecklenburg et al. 2012); the radiometric performance (Kainulainen et al. 2012); the SMOS soil moisture retrieval algorithm (Kerr et al. 2012b; Mattar et al. 2012); the impact of radio frequency interference (RFI) on the SMOS soil moisture measurements (Castro et al. 2012; Misra and Ruf 2012; Oliva et al. 2012);

Table 2 Key benefits expected from satellite soil moisture observations

\begin{tabular}{|c|c|c|}
\hline Area & Products & Comment \\
\hline Meteorology & NWP models & $\begin{array}{l}\text { Soil moisture plays a fundamental role in the transfer of water and } \\
\text { energy between the surface and the atmosphere. Introduction of } \\
\text { this variable in current NWP models will allow improving } \\
\text { predictions, especially important under adverse meteorological } \\
\text { conditions }\end{array}$ \\
\hline Climatology & Models & $\begin{array}{l}\text { Variability of the soil moisture time series with a long integration } \\
\text { period may provide relevant information for the study of climate } \\
\text { change }\end{array}$ \\
\hline \multirow[t]{4}{*}{$\begin{array}{l}\text { Risk } \\
\text { Management }\end{array}$} & Flooding risk map & $\begin{array}{l}\text { The soil's risk of flooding is significantly conditioned by the } \\
\text { amount of water stored in the vadose zone. The generation of this } \\
\text { type of products will require the inclusion of soil moisture data in } \\
\text { hydrological and NWP models (precipitation predictions) }\end{array}$ \\
\hline & Fire risk map & $\begin{array}{l}\text { The risk of fire is determined by several factors, including } \\
\text { meteorological, geophysical and biophysical factors. The } \\
\text { information on soil moisture may be directly assimilated in } \\
\text { drawing up fire risk maps as they provide direct information on } \\
\text { evapotranspiration, water content assimilated by vegetation and } \\
\text { quality of vegetation }\end{array}$ \\
\hline & Famine risk map & $\begin{array}{l}\text { The merging of geopolitical, meteorological/climatological } \\
\text { information and data in the quality and estimates of agricultural } \\
\text { and/or marine products (derived with the help of soil moisture } \\
\text { data) may be of great use in early prediction of famine episodes } \\
\text { in areas of Earth where resources are scarce }\end{array}$ \\
\hline & Drought risk model & $\begin{array}{l}\text { Analysing soil moisture trends in large areas may serve to generate } \\
\text { drought models, along with data from other sensors }\end{array}$ \\
\hline Agriculture & $\begin{array}{l}\text { Agricultural } \\
\text { production } \\
\text { estimate }\end{array}$ & $\begin{array}{l}\text { On the basis of soil moisture data and by means of the application } \\
\text { of hydrological models, it is possible to determine the amount of } \\
\text { water assimilated by the vegetation, a value that is very useful for } \\
\text { estimating agricultural production }\end{array}$ \\
\hline Hydrology & Models & $\begin{array}{l}\text { The content of water stored in the soil is an important parameter to } \\
\text { be taken into consideration in any hydrological model, as it is an } \\
\text { indispensable variable in understanding the water cycle }\end{array}$ \\
\hline
\end{tabular}

Table adapted from http://www.cp34-smos.icm.csic.es/index.htm 
soil processes in boreal regions (Rautiainen et al. 2012); disaggregation of SMOS data (Merlin et al. 2012); and various aspects of the validation of SMOS soil moisture data (Al Bitar et al. 2012; Bircher et al. 2012; dall'Amico et al. 2012; Jackson et al. 2012; Lacava et al. 2012; Mialon et al. 2012; Peischl et al. 2012b; Rowlandson et al. 2012; Sanchez et al. 2012; Schlenz et al. 2012; Schwank et al. 2012).

In view of the applications discussed later in this paper, we briefly mention that snow measurements are often provided by AMSR-E to measure snow water equivalent (SWE), and MODIS (MODerate resolution Imaging Spectroradiometer, Morisette et al. 2002) to give a picture of the snow-covered area. Finally, it is worth to mention GRACE (Gravity Recovery And Climate Experiment, Tapley et al. 2004) for its ability to measure an integrated water quantity of soil moisture and snow, as well as water in deeper layers.

Satellite instruments do not measure directly hydrological parameters. What they measure is photon counts (level 0 data). Algorithms then transform the level 0 data into radiances (level 1 data). Subsequently, using retrieval techniques (Rodgers 2000), retrievals of layer quantities (e.g., of soil moisture) or integrated amounts (e.g., total water storage) are derived (level 2 data). Fields derived from manipulation of level 2 data, for example, by interpolation to a common grid are termed level 3 data. Analyses derived from the assimilation of level 1 and/or 2 data are termed level 4 data.

Satellite observations (from level 0 and up) have associated with them a number of errors, including random and systematic errors in the measurement, and the error of representativeness (or representativity). Random errors (sometimes termed precision) have the property that averaging the data can reduce them. This is not the case of the systematic error or bias (sometimes termed accuracy). The error of representativeness is associated with the extent to which the measurement represents a point or volume in space. In land surface measurements, the error of representativeness is important to consider in comparisons of coarse-scale satellite data with point data.

Satellite-based hydrological data are becoming increasingly available, although little progress has been made in understanding their observational errors. Evaluation of the accuracy of land surface satellite data is a challenge, and novel methods to characterize their errors are being applied. Examples include triple collocation (e.g., Scipal et al. 2008; Dorigo et al. 2010; Parinussa et al. 2011); the R-metrics approach (Crow 2007; Crow and Zhan 2007; Crow et al. 2010); and data assimilation (Houser et al. 2010, and references therein).

A number of in situ network and airborne hydrological studies have been set up in the last decade for evaluation of satellite data. Examples of in situ networks include SMOSMANIA in France (Calvet et al. 2007; Albergel et al. 2009); NVE (Norges vassdrags-og energidirektorat, Norwegian Water Resources and Energy Directorate) in Norway (http://www.nve.no/en/); several large-scale (larger than 10,000 $\mathrm{km}^{2}$ ) networks in the USA and elsewhere (see Table 1 in Crow et al. 2012); and several local- to regional-scale (larger than $100 \mathrm{~km}^{2}$, smaller than $10,000 \mathrm{~km}^{2}$ ) networks in the USA and elsewhere (see Table 2 in Crow et al. 2012). In situ soil moisture data from various networks across the world are consolidated in the International Soil Moisture Network (ISMN; http://www.ipf.tuwien.ac. at/insitu). As of January 2013, the ISMN includes data from 37 networks-Table 3 provides details. An example of an airborne study on evaluation of satellite data is the Australian Airborne Cal/Val Experiments for SMOS (AACE, Peischl et al. 2012a). An example of in situ ground-based station data used to evaluate satellite data is SMOSREX (de Rosnay et al. 2006). The temporal scale of in situ platforms ranges from minutes to hours; the spatial scale of in situ platforms ranges from tens of metres (individual stations) to thousands of kilometres (regional-scale networks). Along with the availability of dense 
Table 3 Contributing networks to the International Soil Moisture Network (ISMN)

\begin{tabular}{|c|c|c|c|}
\hline Name & Country & Stations & Website \\
\hline AACES & Australia & 49 & $\begin{array}{l}\text { http://www.moisturemap.monash. } \\
\text { edu.au/ }\end{array}$ \\
\hline AMMA & Benin, Niger, Mali & 7 & http://amma-international.org/ \\
\hline ARM & USA & 25 & http://www.arm.gov \\
\hline AWDN & USA & 50 & http://www.hprcc.unl.edu/awdn/ \\
\hline CALABRIA & Italy & 5 & http://www.cfcalabria.it \\
\hline CAMPANIA & Italy & 2 & http://www.regione.campania.it/ \\
\hline CHINA & China & 40 & \\
\hline COSMOS & $\begin{array}{l}\text { USA, Germany, } \\
\text { Switzerland, } \\
\text { France, Brasil, Kenya, } \\
\text { UK, Mexico }\end{array}$ & 67 & http://cosmos.hwr.arizona.edu/ \\
\hline FLUXNET-AMERIFLUX & USA & 2 & $\begin{array}{l}\text { http://www.fluxnet.ornl.gov/ } \\
\text { fluxnet/index.cfm }\end{array}$ \\
\hline FMI & Finland & 1 & http://fmiarc.fmi.fi/ \\
\hline GTK & Finland & 7 & \\
\hline HOBE & Denmark & 30 & http://www.hobe.dk/ \\
\hline HSC_SELMACHEON & Korea & 1 & http://www.hsc.re.kr \\
\hline HYDROL-NET_PERUGIA & Italy & 1 & http://www.dica.unipg.it/DICA \\
\hline HYU_CHEONGMICHEON & Korea & 1 & $\begin{array}{l}\text { http://wrrsl.hanyang.ac.kr/html/ } \\
\text { introduction.htm }\end{array}$ \\
\hline $\mathrm{ICN}$ & USA & 19 & http://www.isws.illinois.edu/warm \\
\hline IIT_KANPUR & India & 1 & http://www.iitk.ac.in \\
\hline IOWA & USA & 6 & \\
\hline MAQU & China & 20 & \\
\hline MetEROBS & Italy & 1 & $\begin{array}{l}\text { http://mistrals.sedoo.fr/HyMeX/ } \\
\text { Plateform-search?datsId=532 }\end{array}$ \\
\hline MOL-RAO & Germany & 2 & http://www.dwd.de/mol \\
\hline MONGOLIA & Mongolia & 44 & \\
\hline OZNET & Australia & 52 & http://www.oznet.org.au/ \\
\hline REMEDHUS & Spain & 23 & http://campus.usal.es/ hidrus/ \\
\hline RUSWET-AGRO & Former Soviet Union & 78 & \\
\hline RUSWET-GRASS & Former Soviet Union & 122 & \\
\hline RUSWET-VALDAI & Former Soviet Union & 3 & \\
\hline SCAN & USA & 182 & http://www.wcc.nrcs.usda.gov/scan/ \\
\hline SMOSMANIA & France & 21 & http://www.hymex.org/ \\
\hline SNOTEL & USA & 374 & http://www.wcc.nrcs.usda.gov/snow/ \\
\hline SWEX_POLAND & Poland & 6 & \\
\hline UDC_SMOS & Germany & 11 & $\begin{array}{l}\text { http://www.geographie.uni- } \\
\text { muenchen.de/department/fiona/ } \\
\text { forschung/projekte/index.php? } \\
\text { projekt_id=103 }\end{array}$ \\
\hline UMBRIA & Italy & 7 & $\begin{array}{l}\text { http://www.cfumbria.it/ } \\
\text { http://hydrology.irpi.cnr.it/ }\end{array}$ \\
\hline UMSUOL & Italy & 1 & \\
\hline
\end{tabular}


Table 3 continued

\begin{tabular}{llrl}
\hline Name & Country & Stations & Website \\
\hline USCRN & USA & 114 & http://www.ncdc.noaa.gov/crn/ \\
USDA-ARS & USA & 4 & \\
VAS & Spain & 3 & http://nimbus.uv.es/ \\
\hline
\end{tabular}

Table adapted from http://www.ipf.tuwien.ac.at/insitu/index.php/insitu-networks.html

in situ data for validation, it is also important to select appropriate validation measures (Entekhabi et al. 2010b).

The assimilation of satellite data for land surface applications has only gained significance in the last decade; it started later than atmospheric and oceanographic data assimilation (see various chapters in Lahoz et al. 2010a). This can be attributed to: (1) a lack of dedicated land surface state (water and energy) remote sensing instruments; (2) inadequate retrieval algorithms for deriving global land surface information from remote sensing observations; and (3) a lack of mature techniques to objectively improve and constrain land surface model predictions using remote sensing data.

\section{Models of the Hydrological Cycle}

As discussed above, observational information has gaps in space and time. It is desirable to fill in these observational gaps using a model. Such models can range from simple linear interpolation to full land surface models (LSMs). Land surface processes are part of the global processes controlling the Earth, which are typically represented in global general circulation models (GCMs). The land component in these models is represented in (largely physically based) LSMs, which simulate the water and energy balance over land using simple algebraic equations or more complex systems of partial differential equations. The main state variables of these models include the water content and temperature of soil moisture, snow and vegetation. These variables are referred to as prognostic state variables. Changes in these state variables account for fluxes, for example, evapotranspiration and run-off, which are referred to as diagnostic state variables.

Most land surface models used in GCMs view the soil column as the fundamental hydrological unit, ignoring the role of, for example, topography on spatially variable processes (Stieglitz et al. 1997) to limit the complexity and computations for these coupled models. During the last decades, LSMs have become increasingly complex to accommodate for better understood processes, like snow and vegetation. Along with a more complex structure often comes a more complex parametrization, and several authors (Beven 1989; Duan et al. 1992) have stated that LSMs are over-parametrized given the data typically available for calibration. At larger scales, these models often rely on satellite-observed parameters, such as greenness and LAI (leaf area index). For field-scale studies, the LSMs are usually calibrated to specific circumstances to limit systematic prediction errors. Model calibration or parameter estimation relies on observed data and can be defined as a specific type of data assimilation (Nichols 2010).

Many LSMs have been developed and enhanced since the mid-1990s, with varying features, such as sub-grid variability, community-wide input, advanced physical representations and compatibility with atmospheric models (Houser et al. 2010). Some examples of widely used LSMs are the NCAR Community Land Model (CLM) (Oleson et al. 2010); the Variable Infiltration Capacity (VIC) Model (Liang et al. 1994); the Noah Model (Ek 
et al. 2003); the Catchment LSM (Koster et al. 2000); the TOPMODEL-based Land Atmosphere Transfer Scheme (TOPLATS) model (Famiglietti and Wood 1994); the Hydrology-Tiled European Centre for Medium-range Weather Forecasts (ECMWF) Scheme for Surface Exchange over Land (H-TESSEL) model (Balsamo et al. 2009); the SURFEX model (Le Moigne 2009); the Interaction between Soil Biosphere and Atmosphere (ISBA) model (Noilhan and Mahfouf 1996); and the Joint UK Land Environment Simulator (JULES) model (Best et al. 2011; Clark et al. 2011a). An example of an integrated system is the NASA Land Information System (LIS), which offers the capability to simulate with different models, observations and data assimilation techniques (Kumar et al. 2008).

An LSM has several elements, including a soil moisture scheme, a snow scheme, a rainfall-run-off scheme and a routing/hydraulic scheme. The soil moisture scheme can take several forms, such as explicit numerical solutions of Richards' equations over multiple discretized layers (e.g., in CLM), or using a force-restore method (e.g., Deardorff 1977, used in SURFEX), or other more non-traditional approaches, such as a soil moisture calculation as a deviation from the equilibrium soil moisture profile between the surface and the water table (Catchment LSM). The different profile structures involve different state variables, for example, describing soil moisture at the surface (superficial volumetric water content) or describing soil moisture over the root zone (mean volumetric content of the root zone). The coupling strength between the surface and deeper soil layers is a sensitive point for successful propagation of surface observations to deeper layers (Kumar et al. 2009).

The presence of snow covering the ground and vegetation can greatly influence the energy and mass transfers between the land surface and the atmosphere. Notably, the snow layer modifies the radiative balance by increasing the albedo. Furthermore, the amount of water stored in the snowpack has an important impact on water availability in the spring time. The prognostic variables in most snow schemes include variables related to snow water equivalent (SWE), including snow depth and density, and the snow heat content. These variables most often determine the diagnostics such as snow area extent and albedo.

The snow scheme can have one layer, or several layers. In a one-layer scheme, the evolution of the snow water equivalent of the snow reservoir depends on the precipitation of snow (a source) and the snow sublimation from the snow surface (a sink). Multi-layer schemes are often designed to have intermediate complexity, having simplified physical parametrizations based on those of highly detailed internal-process snow models, while having computational requirements resembling those of single-layer schemes (Loth et al. 1993; Lynch-Stieglitz 1994; Sun et al. 1999).

A number of approaches have been implemented for rainfall-run-off schemes. Water that cannot be stored in the soil profile either runs off over land (Horton run-off, e.g., Decharme and Douville 2006) or gravitationally drains out of the profile (Mahfouf and Noilhan 1996; Boone 1999). The TOPMODEL run-off approach combines key distributed effects of channel network topology and dynamic contributing areas for run-off generation (Beven and Kirkby 1979; Silvapalan et al. 1987). This formalism takes explicit account of topographic heterogeneities (Decharme et al. 2006; Decharme and Douville 2006, 2007). Run-off and drainage exiting from hydrological models can be used as a boundary to hydraulic models that predict river flow and potential flooding (Matgen et al. 2010).

A hydraulic flood routing scheme uses numerical methods to solve simultaneously the equations of continuity and momentum for a fluid (see, e.g., Guo 2006). It is often applied to a river network, typically in a hierarchy including hillslope routing, sub-network routing and main channel routing. An example of a routing scheme is the river transport model 
developed for the NCAR Community Land Model (CLM) (Branstetter and Erickson III 2003, and references therein). A river transport model is also useful because it can be used to evaluate the performance of an LSM against gauge station data.

Most LSMs are soil-vegetation-atmosphere transfer (SVAT) models, where the vegetation is not a truly dynamic component. Recently, coupling of hydrological or SVAT models with vegetation models has received some attention, to serve more specific ecological, biochemical or agricultural purposes. Dynamic vegetation models are used to simulate the evolution of vegetation cover, photosynthesis, carbon and nutrient inventories and the fluxes of water, $\mathrm{CO}_{2}, \mathrm{CH}_{4}, \mathrm{~N}_{2} \mathrm{O}$, volatile organic carbon and fire-related emissions between the land surface and atmosphere. Illustrative examples of vegetation models are the Land biosphere Process and eXchange (LPX) model (Wania 2007; Spahni et al. 2010) and the CoupModel (Gustafsson et al. 2004; Jansson and Karlberg 2004; Jansson et al. 2005, 2008; Karlberg et al. 2006, 2007; Klemedtsson et al. 2008; Norman et al. 2008; Svensson et al. 2008).

There are a number of potential problems with LSMs that can cause errors in the forecast. These include components that cause "model error" and components that cause "predictability error". Components that cause "model error" are as follows: incomplete description of physical processes perhaps done for computational efficiency, perhaps a reflection of incomplete knowledge; inaccurate parameters; and inaccurate forcings. Components that cause "predictability error" are inaccurate initial states and boundaries. All these problems are the subject of research in the land surface modelling and assimilation community.

\section{Data Assimilation of the Hydrological Cycle}

\subsection{Introduction}

The only practical way to observe the land surface on continental to global scales is by satellite remote sensing. However, this cannot provide information on the entire system, and measurements only represent a snapshot in time. Land surface models can predict spatial/temporal land system variations, but these predictions are often poor, due to model initialization, parameter and forcing errors and inadequate model physics and/or resolution. A way forward is to merge the observational and model information through data assimilation (Kalnay 2003).

Mathematics provides rules for combining information objectively, based on principles which aim to maximize (or minimize) a quantity (e.g., a "penalty function") or on established statistical concepts (e.g., Bayesian methods) that relate prior information (understanding, which comes from prior combination of observations and models), with new information (e.g., an extra observation). The merged product, termed the posterior estimate or an analysis, adds value to both observational and model information. The data assimilation methodology takes account of the different nature (e.g., spatio-temporal resolution) of the observational and model information, using an observation operator (see, e.g., Talagrand 2010a).

Assimilation of land surface observations is at an earlier stage than, for example, assimilation of atmospheric observations (see various chapters in Lahoz et al. 2010a). However, during the past decade, land data assimilation has been a very active field of research. Land data assimilation considers both ground-based in situ data and satellite data. Often, satellite land surface data are assimilated and the process validated using in situ 
measurements. Assimilated satellite observations include retrievals of land surface temperature, soil moisture, snow water equivalent (SWE) and snow cover area (e.g., Van den Hurk et al. 2002; Andreadis and Lettenmaier 2006; Slater and Clark 2006; Bosilovich et al. 2007; Dong et al. 2007; Drusch 2007; Ni-Meister 2008; Reichle et al. 2008; Houser et al. 2010). Houser (2003) discusses the assimilation of land surface retrieved quantities and radiances. Early reviews of land data assimilation have been provided by McLaughlin (2002), Reichle (2008), Moradkhani (2008) and Houser et al. (2010).

Land data assimilation uses observations to constrain the physical parametrizations and initialization of land surface states critical for seasonal-to-interannual prediction. These constraints can be imposed in four ways: (1) by forcing the land surface primarily by observations (such as precipitation and radiation), often severe atmospheric NWP land surface forcing biases can be avoided (e.g., Saha et al. 2010; Reichle et al. 2011); (2) by employing innovative land surface data assimilation techniques, observations of land surface storages (such as snow, soil temperature and moisture) can be used to constrain unrealistic simulated storages (e.g., Houser et al. 2010; Reichle et al. 2013); (3) by tuning adjustable parameters (e.g., Pauwels et al. 2009; Vrugt et al. 2012); and (4) the land surface physical structure itself can be improved through the data assimilation process when the constant confrontation of model states against observations returns useful information about structural deficits. Integration of soil moisture information from satellite instruments, and ground-based and in situ observations of the land surface, using land data assimilation, provides a comprehensive picture of the state and variability of the land surface.

\subsection{Data Assimilation Methods}

Three methods are commonly used for land data assimilation (Houser et al. 2010): variational (3- and 4-dimensional, 3D-Var and 4D-Var); sequential (Kalman filter (KF) and Extended Kalman filter (EKF)); and ensemble (Ensemble Kalman filter, EnKF). Bouttier and Courtier (1999) provide details of these methods. Talagrand (2010a) and Kalnay (2010) discuss more recent developments in variational methods and ensemble methods, respectively.

In the $3-D$ variational (3D-Var) method, a minimization algorithm is used to find a model state, $\mathbf{x}$, that minimizes the misfit between $\mathbf{x}$ and the background state $\mathbf{x}^{b}$, and also between the observation predictions $H(\mathbf{x})$ and the observations $\mathbf{y}$. The observation operator $H$ maps the model state $\mathbf{x}$ to the measurement space, where $\mathbf{y}$ resides. In 3D-Var, we seek the minimum with respect to $\mathbf{x}$ of the penalty function, $J$, given by Eq. (1). The first term on the right hand side $\left(J_{\mathrm{b}}\right)$ quantifies the misfit to the background term, and the second term $\left(J_{\mathrm{o}}\right)$ is the misfit to the observations. If the observation operator is linear (written $\mathbf{H}$ ), the penalty function, $J$, is quadratic and is guaranteed to have a unique minimum.

$$
J=\frac{1}{2}\left[x-x^{b}\right]^{\mathrm{T}} \mathbf{B}^{-1}\left[x-x^{b}\right]+\frac{1}{2}[y-H(x)]^{\mathrm{T}} \mathbf{R}^{-1}[y-H(x)]
$$

4-D variational (4D-Var) assimilation is an extension of 3D-Var in which the temporal dimension is included, that is, 4D-Var is a smoother. In 4D-Var, observations are used at their correct time. 4D-Var has two new features compared to 3D-Var. First, it includes a model operator, $M$, that carries out the evolution forward in time. The first derivative, or differential, of $M, \mathbf{M}$, is the tangent linear model (if $M$ is linear, represented by $\mathbf{M}$, its derivative is $\mathbf{M})$. The transpose of the tangent linear model operator, $\mathbf{M}^{\mathrm{T}}$, integrates the adjoint variables backward in time. The tangent linear model is only defined under the condition that the function $J$ defined by Eq. (1) be differentiable-this is the tangent linear 
hypothesis. Second, $J$ can include an extra term in which the model errors associated with the model's temporal evolution are accounted for. In the formulation of Zupanski (1997), an analogous term involving $\mathbf{Q}^{-1}$ is included in $J$, where $\mathbf{Q}$ is the model error covariance. Examples for the land surface using variational methods include Calvet et al. (1998) and Reichle et al. (2001a). Note that variational methods are very common for parameter estimation (e.g., Dumont et al. 2012), but with replacement of the misfit to the background with a misfit to prior parameter guesses.

In the Kalman filter $(\mathrm{KF})$, a recursive sequential algorithm is applied to evolve a forecast, $\mathbf{x}^{f}$, and an analysis, $\mathbf{x}^{a}$, as well as their respective error covariance matrices, $\mathbf{P}^{f}$ and $\mathbf{P}^{a}$. The KF equations are (subscripts denote the time step) as follows:

$$
\begin{gathered}
x_{n}^{f}=\mathbf{M}_{n-1} x_{n-1}^{a} ; \\
\mathbf{P}_{n}^{f}=\mathbf{M}_{n-1} \mathbf{P}_{n-1}^{a} \mathbf{M}_{n-1}^{\mathrm{T}}+\mathbf{Q}_{n-1} ; \\
x_{n}^{a}=x_{n}^{f}+\mathbf{K}_{n}\left[y_{n}-\mathbf{H}_{n} x_{n}^{f}\right] ; \\
\mathbf{K}_{n}=\mathbf{P}_{n}^{f} \mathbf{H}_{n}^{\mathrm{T}}\left[\mathbf{R}_{n}+\mathbf{H}_{n} \mathbf{P}_{n}^{f} \mathbf{H}_{n}^{\mathrm{T}}\right]^{-1} ; \\
\mathbf{P}_{n}^{a}=\left[\mathbf{I}-\mathbf{K}_{n} \mathbf{H}_{n}\right] \mathbf{P}_{n}^{f} .
\end{gathered}
$$

Equation (2a) represents the forecast of the model fields from time step $n-1$ to $n$, while Eq. (2b) calculates the forecast error covariance from the analysis error covariance $\mathbf{P}^{a}$ and the model error covariance $\mathbf{Q}$. Equations (2c) and (2e) are the analysis steps, using the Kalman gain defined in Eq. (2d). $\mathbf{Q}$ and $\mathbf{P}^{a}$ are assumed to be uncorrelated. For optimality, all errors must be uncorrelated in time.

The KF can be generalized to nonlinear $H$ and $M$ operators, although in this case neither the optimality of the analysis nor the equivalence with 4D-Var holds. The resulting equations are known as the Extended Kalman filter (EKF) as, for example, used for the land surface by Boulet et al. (2002), Reichle et al. (2002b), Matgen et al. (2010), Rüdiger et al. (2010) and de Rosnay et al. (2012b).

The Ensemble Kalman filter, EnKF, uses a Monte Carlo ensemble of short-range forecasts to estimate $\mathbf{P}^{f}$. The estimation becomes more accurate as the ensemble size increases. The EnKF is more general than the EKF to the extent that it does not require validity of the tangent linear hypothesis. Evensen (2003) provides a comprehensive review of the theory and numerical implementation of the EnKF. Examples for the land surface are identified in Table 4 (see below).

The Particle Filter (PF) is also an ensemble method. It does not require a specific form for the state distribution but, typically, a re-sampling algorithm needs to be applied (van Leeuwen 2009). Because PF methods typically make no assumptions of linearity in the model equations or that model and observational errors are Gaussian, they are well suited to deal with the land surface where model evolution is highly nonlinear, and model and observational errors can be non-Gaussian. The PF has been applied in hydrology to estimate model parameters and state variables (e.g., Moradkhani et al. 2005a; Weerts and El Serafy 2006; Plaza et al. 2012; Vrugt et al. 2012).

\subsection{Representation of Errors}

Representation of errors is fundamental to data assimilation. One needs to consider errors in observations, background information and model (see Eqs. (1, 2a-e) above for identification of the error covariance matrices mentioned in the following). $\mathbf{R}$, the observational 
Table 4 Selected studies on land surface data assimilation, sorted by assimilated observation type

\begin{tabular}{|c|c|c|c|}
\hline \multirow[t]{2}{*}{ Observation } & \multicolumn{2}{|l|}{ State } & \multirow[t]{2}{*}{ Parameter/model } \\
\hline & EnKF/EnKS & Other & \\
\hline $\begin{array}{l}\text { Soil moisture, } \\
\text { retrievals }\end{array}$ & $\begin{array}{l}\text { Reichle and Koster } \\
\text { (2005), Ni-Meister et al. } \\
\text { (2006), Reichle et al. } \\
\text { (2007, 2008), Kumar } \\
\text { et al. (2009), Pan and } \\
\text { Wood (2010), Liu et al. } \\
\text { (2011), Han et al. } \\
\text { (2012a), Draper et al. } \\
\text { (2012), Sahoo et al. } \\
\text { (2013) }\end{array}$ & $\begin{array}{l}\text { Houser et al. (1998), } \\
\text { Pauwels et al. (2002), } \\
\text { Paniconi et al. (2003), } \\
\text { Francois et al. (2003), } \\
\text { Hurkmans et al. (2006), } \\
\text { Parajka et al. (2006), } \\
\text { Crow (2007), Crow and } \\
\text { Bolten (2007), Parada } \\
\text { and Liang (2008), Crow } \\
\text { and van den Berg } \\
\text { (2010), Draper et al. } \\
\text { (2009), Mahfouf } \\
\text { (2010), Dharssi et al. } \\
\text { (2011), de Rosnay et al. } \\
\text { (2012a, b) }\end{array}$ & $\begin{array}{l}\text { Santanello et al. (2007), } \\
\text { Ines and Mohanty } \\
\text { (2009), Pauwels et al. } \\
\text { (2009) }\end{array}$ \\
\hline Soil moisture, in situ & $\begin{array}{l}\text { Sabater et al. (2007), De } \\
\text { Lannoy et al. (2007a, } \\
\text { 2009), Camporese et al. } \\
\text { (2009), Monsivais- } \\
\text { Huerteroet et al. (2010), } \\
\text { Han et al. (2012a) }\end{array}$ & $\begin{array}{l}\text { Calvet et al. (1998), } \\
\text { Wingeron et al. (1999), } \\
\text { Walker et al. (2001b, } \\
\text { 2002) }\end{array}$ & $\begin{array}{l}\text { Boulet et al. (2002), De } \\
\text { Lannoy et al. (2006), } \\
\text { Vereecken et al. (2008), } \\
\text { Loew and Mauser } \\
\text { (2008), Nagarajanar } \\
\text { et al. (2011) }\end{array}$ \\
\hline $\begin{array}{l}\text { Snow cover or } \\
\text { albedo, retrievals }\end{array}$ & $\begin{array}{l}\text { Clark et al. (2006), Su } \\
\text { et al. (2008, 2010), De } \\
\text { Lannoy et al. (2012), } \\
\text { Arsenault et al. (2013) }\end{array}$ & $\begin{array}{l}\text { Rodell and Houser } \\
\text { (2004), Zaitchik and } \\
\text { Rodell (2009), Saha } \\
\text { et al. (2010), de Rosnay } \\
\text { et al. (2012a, b) }\end{array}$ & $\begin{array}{l}\text { Essery and Pomeroy } \\
\text { (2004), Déry et al. } \\
\text { (2005), Kolberg and } \\
\text { Gottschalk (2010), } \\
\text { Dumont et al. (2012) }\end{array}$ \\
\hline $\begin{array}{l}\text { Snow water } \\
\text { equivalent, } \\
\text { retrievals or in situ }\end{array}$ & $\begin{array}{l}\text { Andreadis and } \\
\text { Lettenmaier (2006), } \\
\text { Slater and Clark (2006), } \\
\text { Dong et al. (2007), } \\
\text { De Lannoy et al. (2010, } \\
\text { 2012), He et al. (2012) }\end{array}$ & $\begin{array}{l}\text { Brasnett (1999), Sun et al. } \\
\text { (2004), Drusch et al. } \\
\text { (2004) }\end{array}$ & $\begin{array}{l}\text { Clark and Vrugt (2006), } \\
\text { Clark et al. (2011b), } \\
\text { Su et al. (2011) }\end{array}$ \\
\hline $\begin{array}{l}\text { Backscatter, from soil } \\
\text { or vegetation }\end{array}$ & Flores et al. (2012) & $\begin{array}{l}\text { Hoeben and Troch } \\
\text { (2000), Zhan et al. } \\
(2006)\end{array}$ & $\begin{array}{l}\text { Marzahn and Ludwig } \\
\text { (2009), Nearing et al. } \\
\text { (2010) }\end{array}$ \\
\hline $\begin{array}{l}\text { Brightness } \\
\text { temperature, for } \\
\text { soil or vegetation }\end{array}$ & $\begin{array}{l}\text { Margulis et al. (2002), } \\
\text { Reichle et al. (2002a), } \\
\text { Crow (2003), Crow and } \\
\text { Wood (2003), Dunne } \\
\text { and Entekhabi (2006) }\end{array}$ & $\begin{array}{l}\text { Entekhabi et al. (1994), } \\
\text { Galantowicz et al. } \\
\text { (1999), Crosson et al. } \\
\text { (2002), Reichle et al. } \\
\text { (2001a, b), Jones et al. } \\
\text { (2003), Wilker et al. } \\
\text { (2006), Balsamo et al. } \\
\text { (2006), Loew et al. } \\
\text { (2009), Dumedah et al. } \\
\text { (2011) }\end{array}$ & $\begin{array}{l}\text { Zhang et al. (2011), } \\
\text { Montzka et al. (2012), } \\
\text { De Lannoy et al. (2013) }\end{array}$ \\
\hline $\begin{array}{l}\text { Brightness } \\
\text { temperature, for } \\
\text { snow }\end{array}$ & $\begin{array}{l}\text { Durand and Margulis } \\
\text { (2007), Durand et al. } \\
\text { (2009) }\end{array}$ & $\begin{array}{l}\text { DeChant and Moradkhani } \\
\text { (2010) }\end{array}$ & $\begin{array}{l}\text { Tedesco et al. (2010), } \\
\text { Vachon et al. (2010), } \\
\text { Forman et al. (2012a) }\end{array}$ \\
\hline
\end{tabular}


Table 4 continued

\begin{tabular}{|c|c|c|c|}
\hline \multirow[t]{2}{*}{ Observation } & \multicolumn{2}{|l|}{ State } & \multirow[t]{2}{*}{ Parameter/model } \\
\hline & EnKF/EnKS & Other & \\
\hline $\begin{array}{l}\text { Surface soil or skin } \\
\text { temperature, } \\
\text { evapotranspiration, } \\
\text { retrievals or in situ }\end{array}$ & $\begin{array}{l}\text { Pipunic et al. (2008), } \\
\text { Ghent et al. (2010), } \\
\text { Reichle et al. (2010), } \\
\text { Xu et al. (2011) }\end{array}$ & $\begin{array}{l}\text { Castelli et al. (1999), } \\
\text { Lakshmi (2000), } \\
\text { Boni et al. (2001), } \\
\text { Schuurmans et al. } \\
\text { (2003), Bosilovich et al. } \\
\text { (2007), Renzullo et al. } \\
\text { (2008), Sini et al. } \\
\text { (2008), Meng et al. } \\
\text { (2009), Barrett and } \\
\text { Renzullo (2009), } \\
\text { Mackaro et al. (2011) }\end{array}$ & $\begin{array}{l}\text { Caparrini et al. (2004), } \\
\text { Kalma et al. (2008), } \\
\text { Gutmann and Small } \\
\text { (2010) }\end{array}$ \\
\hline $\begin{array}{l}\text { Water stage, } \\
\text { retrievals }\end{array}$ & $\begin{array}{l}\text { Andreadis et al. (2007), } \\
\text { Durand et al. (2008), } \\
\text { Biancamaria et al. } \\
\text { (2010) }\end{array}$ & $\begin{array}{l}\text { Matgen et al. (2010), } \\
\text { Giustarini et al. (2011) }\end{array}$ & Montanari et al. (2009) \\
\hline $\begin{array}{l}\text { Terrestrial water } \\
\text { storage, retrievals }\end{array}$ & $\begin{array}{l}\text { Zaitchik et al. (2008), Su } \\
\text { et al. (2010), Li et al. } \\
\text { (2012), Forman et al. } \\
\text { (2012b) }\end{array}$ & - & $\begin{array}{l}\text { Günter (2008), Lo et al. } \\
\text { (2010) }\end{array}$ \\
\hline Discharge, gauge & $\begin{array}{l}\text { Weerts and El Serafy } \\
\text { (2006), Vrugt et al. } \\
\text { (2006), Pauwels and De } \\
\text { Lannoy }(2006,2009)\end{array}$ & $\begin{array}{l}\text { Aubert et al. (2003), } \\
\text { Moradkhani et al. } \\
\text { (2005a), Seo et al. } \\
\text { (2009), Lee et al. } \\
\text { (2011), Vrugt et al. } \\
\text { (2012) }\end{array}$ & $\begin{array}{l}\text { Madsen (2003), } \\
\text { Moradkhani et al. } \\
\text { (2005b), Montanari and } \\
\text { Toth (2007), Vrugt } \\
\text { et al. (2008), Quets } \\
\text { et al. (2010) }\end{array}$ \\
\hline $\begin{array}{l}\text { Leaf area index, } \\
\text { remotely sensed }\end{array}$ & $\begin{array}{l}\text { Pauwels et al. (2006), } \\
\text { Nearing et al. (2012) }\end{array}$ & $\begin{array}{l}\text { Jarlan et al. (2008), } \\
\text { Albergel et al. (2010), } \\
\text { Rüdiger et al. (2010) }\end{array}$ & Lewis et al. (2012) \\
\hline $\begin{array}{l}\text { Screen-level } \\
\text { observations }\end{array}$ & - & $\begin{array}{l}\text { Balsamo et al. (2004), } \\
\text { Seuffert et al. (2004), } \\
\text { Drusch and Viterbo } \\
\text { (2007), Mahfouf et al. } \\
\text { (2009), Draper et al. } \\
\text { (2011), Mahfouf and } \\
\text { Bliznak (2011) }\end{array}$ & - \\
\hline
\end{tabular}

Synthetic observation studies are classified by the observation type that is mirrored. For land surface (-coupled) state updating, the studies are divided into sets using either the EnKF or EnKS (Ensemble Kalman Smoother) and those using any other assimilation technique. For parameter and model structure updating, examples relate to either forward models or land surface(-coupled) models

error covariance matrix, is typically assumed to be diagonal, although this is not always justified. $\mathbf{R}$ includes errors of the measurements themselves, $\mathbf{E}$, and errors of representativeness, $\mathbf{F} ; \mathbf{R}=\mathbf{E}+\mathbf{F}$. $\mathbf{B}$ is the background error covariance matrix in variational methods (the analogue in the KF and ensemble methods is $\mathbf{P}^{f}$ ); its diagonal elements determine the relative weight of the forecasts, and its off-diagonal elements determine how information is spread spatially. Estimating $\mathbf{B}$ or $\mathbf{P}^{f}$ is a key part of the data assimilation method (Bannister 2008a, b). Estimating model error $\mathbf{Q}$ is a research topic.

In the EnKF, the background (or forecast) errors are represented by the spread of the ensemble. This simplifies the computation of $\mathbf{P}^{f}$, implicitly accounts for the model error $\mathbf{Q}$ and avoids the calculation of Eq. (2b). For land data assimilation, the relative fraction of 
the observation error $\mathbf{R}$ and the model error $\mathbf{Q}$ (associated with the temporal evolution of the model) is often tuned or adaptively updated (e.g., Desroziers et al. 2005; Reichle et al. 2008).

In general, in data assimilation, errors are assumed to be Gaussian. The most fundamental justification for assuming Gaussian errors, which is entirely pragmatic, is the relative simplicity and ease of implementation of statistical linear estimation under these conditions. Because Gaussian probability distribution functions are fully determined by their mean and variance, the solution of the data assimilation problem becomes computationally practical. Note that the assumption of a Gaussian distribution is often not justified in land data assimilation applications.

Typically, there are biases between different observations, and between observations and model (see, e.g., Ménard 2010). These biases are spatially and temporally varying, and it is a major challenge to estimate and correct them. Despite this, and mainly for pragmatic reasons, in data assimilation it is often assumed that errors are unbiased. For NWP many assimilation schemes now incorporate a bias correction, and various techniques have been developed to correct observations to remove biases (e.g., Dee 2005); these methods are now being applied to land data assimilation (De Lannoy et al. 2007a, b).

\subsection{Advantages and Disadvantages of Assimilation Methods}

The feasibility of 4D-Var has been demonstrated in NWP systems (see, e.g., Simmons and Hollingsworth 2002). Its main advantage is that it considers observations over a time window that is generally much longer than the model time step, that is, it is a smoothing algorithm. This allows more observations to constrain the system and, considering satellite coverage, increases the geographical area influenced by the data. For nonlinear systems (as is generally the case for the land surface), this feature of 4D-Var, together with the nondiagonal nature of the adjoint operator which transfers information from observed regions to unobserved regions, reduces the weight of the background error covariance matrix in the final 4D-Var analysis compared to the KF analysis (for linear systems, the general equivalence between 4D-Var and the KF implies that the same weight is given to all data in both systems).

In contrast to the above advantages of $4 \mathrm{D}$-Var, three weaknesses must be mentioned. First, its numerical cost is very high compared to approximate versions of the KF or ensemble methods. Second, its formalism cannot determine the analysis error directly; rather, it has to be computed from the inverse of the Hessian matrix (again, this procedure is prohibitive in both computation time and memory). Finally, its formalism requires the calculation of the adjoint model, which is time-consuming and may be difficult for a system such as the land surface which exhibits nonlinearities and on-off processes (e.g., presence or lack of snow).

The EKF is capable of handling some departure from Gaussian distributions of model errors and nonlinearity of the model operator. However, if the model becomes too nonlinear or the errors become highly skewed or non-Gaussian, the trajectories computed by the EKF will become inaccurate.

The EnKF is attractive as, for example, it requires no derivation of a tangent linear operator or adjoint equations and no integrations backward in time, as for 4D-Var (see Evensen 2003). The EnKF also provides a cost-effective representation of the background error covariance matrix, $\mathbf{P}^{f}$. Several issues need to be considered in developing the EnKF: (1) ensemble size; (2) ensemble collapse; (3) correlation model for $\mathbf{P}^{f}$, including localization (see, e.g., Kalnay 2010); and (4) specification of model errors. 
The major drawback of the above techniques is the underlying assumption that the model states have a Gaussian distribution. The PF does not require a specific form for the state distribution, but its major drawback is that distribution of particle weights quickly becomes skewed, and a re-sampling algorithm needs to be applied.

The EnKF and PF are complementary. This complementarity makes a hybrid EnKF/PF version highly attractive for systems that can exhibit nonlinear and non-Gaussian features, an example being the land surface. For example, the EnKF could be used as an efficient sampling tool to create an ensemble of particles with optimal characteristics with respect to observations. The PF methodology could then be applied on that ensemble afterwards to resolve nonlinearity and non-Gaussianity in the system. This method is getting increased attention (see, e.g., Kotecha and Djurić 2003).

\subsection{Example of a Land Data Assimilation System}

For illustrative purposes, we describe the elements of the NILU SURFEX-EnKF land data assimilation system (Lahoz et al. 2010b). These elements are the following: (1) a data assimilation scheme (mainly variants of the EnKF, but also variants of the PF, and the EKF); (2) a land surface model (SURFEX model developed at Météo-France, Le Moigne 2009); (3) observations; (4) the observation operator; and (5) error characteristics for the model and the observations.

The SURFEX model used at NILU (and at Météo-France) can be run in uncoupled or coupled mode. It includes the following elements:

- A soil and vegetation scheme: ISBA and ISBA-A-gs;

- A water surface scheme: COARE/ECUME (Coupled Ocean-Atmosphere Response Experiment/Exchange Coefficients from Unified Multi-campaign Estimates) for the sea; FLAKE for inland water;

- Urban and artificial areas: Town Energy Balance-TEB model;

- A surface boundary layer (SBL) scheme;

- Chemistry and aerosols;

- A land use database: ECOCLIMAP.

Figure 3 illustrates how SURFEX works. During a model time step, each surface grid box receives from the atmosphere the following information: upper air temperature, specific humidity, horizontal wind components, pressure, total precipitation, long-wave radiation, short-wave direct and diffuse radiation and, possibly, concentrations of chemical species and dust. In return, SURFEX computes averaged fluxes of momentum, sensible and latent heat, and, possibly, chemical species and dust fluxes. These fluxes are then sent back to the atmosphere with the addition of radiative terms like surface temperature, surface direct and diffuse albedo, and surface emissivity.

The above information transferred to the atmosphere from the land surface provides the lower boundary conditions for the radiation and turbulent schemes in an atmospheric model coupled to SURFEX or forced by SURFEX output. In SURFEX, each grid box is made up of four adjacent surfaces: one for nature, one for urban areas, one for sea or ocean and one for lake, identified by the global ECOCLIMAP land database. The SURFEX fluxes are the average of the fluxes computed over nature, town, sea/ocean or lake, weighted by their respective fraction.

The assimilation system at NILU is illustrated in Fig. 4 with reference to the EnKF. It can assimilate the following data: (1) 2-m screen-level temperature $\left(T_{2 \mathrm{~m}}\right)$ and 2-m screenlevel relative humidity $\left(\mathrm{RH}_{2 \mathrm{~m}}\right)$ provided, for example, by the SYNOP/CANARI 


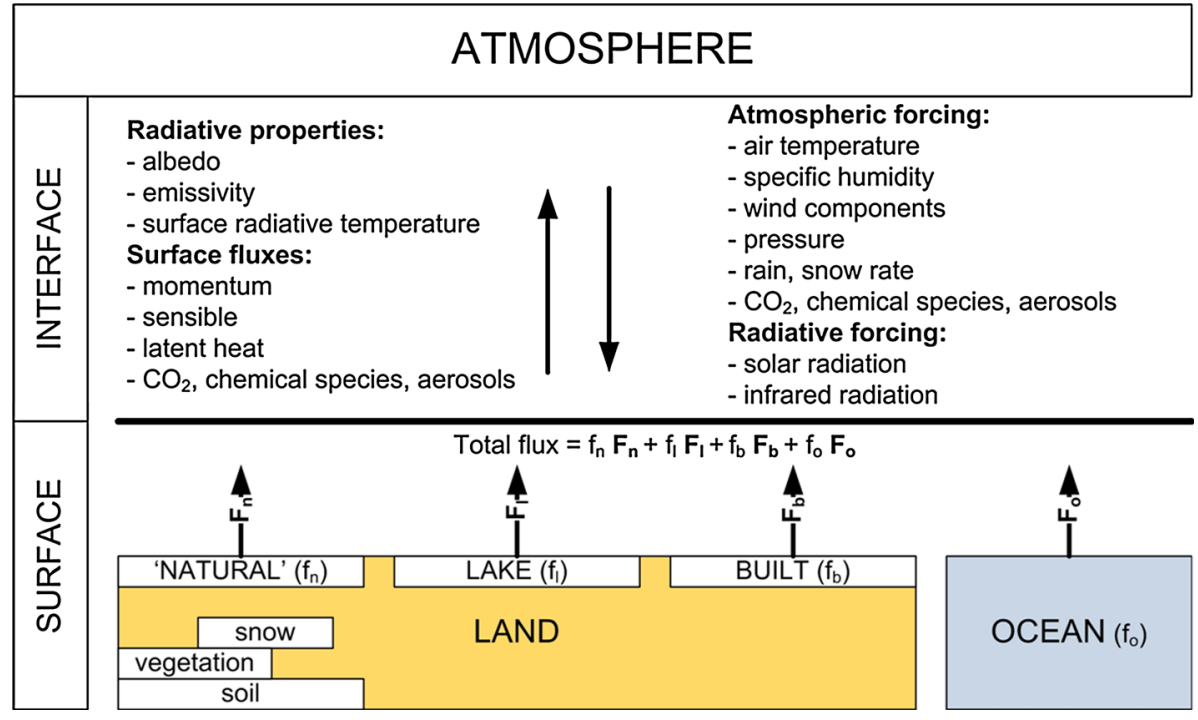

Fig. 3 Exchanges between the atmosphere and land surface implemented in the SURFEX LSM. See text. Based on Le Moigne (2009)

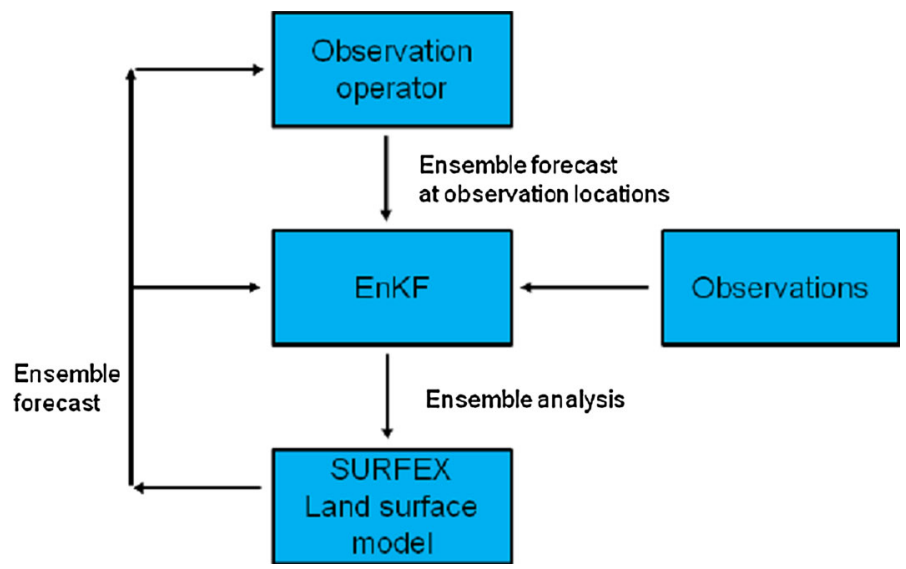

Fig. 4 Schematic of the NILU SURFEX-EnKF land DA system methodology. From Lahoz et al. (2010b)

(Code d'Analyse Nécessaire à Arpege pour ses Rejets et son Initialisation; Taillefer 2002) analysis; and (2) superficial soil moisture content data from satellites (e.g., from ASCAT, AMSR-E and SMOS). The control variables (Nichols 2010) of the NILU land DA system are the following:

- Surface temperature;

- Mean surface temperature;

- Superficial volumetric water content;

- Mean volumetric water content of the root zone. 


\subsection{Data Assimilation Research Applications}

Table 4 shows a selection of studies using a variety of observation types to improve the land surface state or the state in a hydraulic, vegetation or snow model coupled to it. Because of its success in highly nonlinear land surface modelling (Reichle 2008), the EnKF has gained a lot of attention. Therefore, state estimation studies using an EnKF or EnKS (Ensemble Kalman Smoother, where the time integration is done forwards and backwards) are organized separately from those that use any other assimilation technique (e.g., variational, optimal interpolation). Also shown are a few examples on parameter estimation in land surface or forward models. While this review focuses on state estimation, parameter estimation and forcing correction are of utmost importance in land surface models. Land surface models are not chaotic and thus benefit less from state estimation than atmospheric or oceanic applications. By contrast, parameters and forcings determine the major part of the land surface model uncertainty, and great advances can be expected from combining state, bias, parameter and forcing estimation (Moradkhani et al. 2005b; De Lannoy et al. 2006; Vrugt et al. 2012). Here, we discuss a number of soil moisture and snow-related studies done mainly for state updating, with particular attention to the conceptual problems they address. Examples on evapotranspiration, surface or skin temperature, LAI (leaf area index), discharge and water stage assimilation are also provided in Table 4, but not discussed in detail.

\subsubsection{Single-column Applications}

To explore the possibilities and limitations of assimilation schemes, numerous studies have first explored single point-scale or grid cell-scale applications. For soil moisture assimilation, conceptual problems include the propagation of information from the surface to the entire soil profile; the optimization of assimilation techniques and update frequencies; and the identification of an allowable level of uncertainty in surface observations to be useful in a data assimilation scheme, mostly in view of satellite sensor design.

Georgakakos and Baumer (1996) performed a sensitivity study to document the impact of observation noise on Kalman filter (KF) results. Calvet et al. (1998) and Wingeron et al. (1999) assimilated surface soil moisture data from a soil profile in the highly instrumented field site of the Monitoring the Usable soil Reservoir EXperiment (MUREX) in France to update root zone soil moisture using variational approaches and investigated the importance of assimilation windows and observation frequencies. Similarly, Li and Islam (1999) studied the effect of assimilation frequency while directly inserting gravimetric measurements as surrogates for remote sensing data, and Aubert et al. (2003) suggested that a 1-week soil moisture update is sufficient. Walker et al. (2001a) showed in a synthetic profile study that the KF was superior to direct insertion. In a subsequent study with real data from the Nerrigundah catchment in Australia, Walker et al. (2001b) articulated the idea that soil moisture assimilation can solve issues with errors in forcings or initial conditions, but not errors caused by problems in the physics of the soil model.

De Lannoy et al. (2007a) used an EnKF to study vertical information propagation, and the effect of assimilation depth and frequency for an extensive set of soil profiles in an USDA field in Beltsville, USA. This study highlighted the effect of bias propagation through the profile and the need for bias estimation, a conceptual problem that was addressed with a two-stage forecast and bias filter (De Lannoy et al. 2007a, b). At the same time, Sabater et al. (2007) studied the concept of propagating surface observations to deeper model layers using different types of filtering, using ground data from the Surface 
Monitoring of the Soil Reservoir EXperiment, SMOSREX. Camporese et al. (2009) set up synthetic soil profile assimilation experiments studying the effect of uncertainties, ensemble size, bias and other factors with an EnKF. Because of the large impact of parameters and forcings on soil moisture errors and biases, assimilation schemes have paid increasing attention to including parameter estimation along with state updating, as, for example, illustrated in Monsivais-Huerteroet et al. (2010). At present, EnKF filtering experiments are being conducted at point-scales to further identify and address conceptual problems with soil profile estimation, using surface observations (see, e.g., Han et al. 2012a).

Another important conceptual problem with soil moisture assimilation, initially addressed in a point-scale setting, is the direct assimilation of radiances or assimilation using an observation operator. This is done to avoid inconsistencies between auxiliary information that would be used in retrievals and that used in the land surface models. Entekhabi et al. (1994) estimated 1-m-deep bare soil moisture profiles using synthetic microwave brightness temperatures. This work was extended by Galantowicz et al. (1999) using eight days of L-band brightness temperature $\left(\mathrm{T}_{\mathrm{b}}\right)$ data collected from a test plot in Beltsville, USA. Pathmathevan et al. (2003) assimilated microwave observations with a variational technique, but using a heuristic optimization, rather than an adjoint. Crosson et al. (2002) tested $\mathrm{T}_{\mathrm{b}}$ assimilation at the point-scale with an EKF and showed that biases could not be overcome through assimilation. Crow (2003) successfully assimilated $T_{b}$ for soil moisture and showed improvements at the plot-scale, using either synthetic or real field data. Crow analysed the EnKF performance in terms of the assumptions that underlie the KF. Crow and Wood (2003) also used the EnKF at two sites within the Southern Great Plains 1997 (SGP97) experimental domain and reported that $\mathrm{T}_{\mathrm{b}}$ data assimilation was able to correct for rainfall errors. Wilker et al. (2006) highlighted the difficulty in mapping heterogeneous soil moisture into $T_{\mathrm{b}}$ using a forward operator and identified the representativeness errors associated with these data. Similar to the above studies, Hoeben and Troch (2000) used a KF including a forward backscatter model to explore the direct assimilation of radar microwave signals to estimate soil moisture profiles.

Snow data assimilation has conceptual problems inherent to the cumulative and temporary nature of this variable. Slater and Clark (2006) illustrated how a square root EnKF could improve the snow state at in situ sites in Colorado during the accumulation and melt phase. They also identified the temporal correlation in snowpacks and showed how it could limit the efficiency of filtering if not accounted for properly. In a synthetic study, Liston and Hiemstra (2008) proposed a technique to update snow retroactively, which would be useful for reanalysis applications, if observations would only be available at the end of the snow season. In situ snow data assimilation is performed operationally (see Sect. 4.7 below), usually with simple assimilation techniques. An example where both the snow state and parameters were estimated using an EnKF in a 1-D setting is given by Su et al. (2011).

A number of point- or single-grid-scale studies have tried to relate brightness temperature data to snowpack characteristics (Durand et al. 2008; Andreadis et al. 2008), in preparation for $\mathrm{T}_{\mathrm{b}}$ assimilation. Many of these studies highlight the large sensitivity of snowpack estimates to model parameters (Davenport et al. 2012), which makes both forward simulation and inversion of $\mathrm{T}_{\mathrm{b}}$ observations for SWE estimation a difficult task.

\subsubsection{Distributed Applications}

The most obvious advantage of remotely sensed observations is the possibility of performing large-scale and spatially distributed assimilation. It should be recognized, 
however, that despite the spatial coverage of data, for computational reasons assimilation is often performed per column, that is, using a 1-D filter. When the vertical columns (of snow or soil) are horizontally connected through the model physics or assimilation statistics, this is referred to as 3-D assimilation.

The assimilation of catchment-distributed soil moisture has often focused on the improvement of the state or initial conditions (Pauwels et al. 2001, 2002) and parameters in order to improve spatially integrated fluxes, such as discharge. However, it is also possible to use soil moisture assimilation to correct rainfall estimates (Crow and Ryu 2009). At the global scale, soil moisture assimilation will become increasingly important when coupled to the atmosphere for climate and seasonal predictions.

Spatially distributed studies initially focused on assimilation of retrievals with simple techniques and gradually developed towards more complex schemes, with the inclusion of forward models (observation operators) to directly assimilate, for example, microwave observations. Initial soil moisture retrieval studies explored the performance of different filter techniques, such as Newtonian nudging, statistical correction and statistical interpolation (Houser et al. 1998; Pauwels et al. 2001; Paniconi et al. 2003; Hurkmans et al. 2006), while during the last decade, variational and KF-based assimilation largely dominated this research field because of the proven robustness and flexibility of these latter techniques (Reichle et al. 2002a, b).

A typical conceptual problem with spatially distributed assimilation is the use of coarsescale remotely sensed data to infer fine-scale information. There are many static disaggregation techniques that use auxiliary information to perform such a downscaling outside the assimilation scheme. Performing dynamic disaggregation within the assimilation scheme remains a research challenge. The latter concept consists of a 3-D filter with inclusion of spatially correlated (fine-scale) state and (coarse-scale) observation prediction errors and has been addressed in EnKF frameworks by Reichle et al. (2001b, 2013), Reichle and Koster (2003), Pan et al. (2009), De Lannoy et al. (2010) and Sahoo et al. (2013).

An important issue connected to 3-D filtering for disaggregation is the use of local observations to update neighbouring locations, for example, to propagate from observed swaths to unobserved locations. Often, this problem is solved with spatial interpolation or by relying on horizontal connections in the model equations (Walker et al. 2002). Alternatively, such horizontal information propagation can be done within an assimilation scheme that provides accurate error correlations between observed and non-observed observations and forecasts (Reichle and Koster 2003; De Lannoy et al. 2012). De Lannoy et al. (2009) used an adaptive KF to identify such spatial correlations, along with the magnitude of the forecast error, to optimize filter performance. Han et al. (2012b) studied the effect of spatial correlations in an OSSE (observing system simulation experiment) with a local ensemble transform Kalman filter. Filter technical issues such as update frequency (Walker and Houser 2004) and error estimation have also been addressed in a spatial context. Reichle and Koster (2005) demonstrated the validity of the concept that assimilation results should be better than either the model or observations alone. After re-scaling satellite observations from AMSR-E and SMMR to take bias out of the system, Reichle et al. (2007) showed that satellite observations can contribute valuable information, even if they are not accurate. Reichle et al. (2009) further assessed the quality of assimilation products as a function of retrieval and land surface model uncertainty in an OSSE and showed that soil moisture retrievals can have slightly less skill than the land surface model and still contribute to an overall higher skill in the assimilation product. This was confirmed in a real data assimilation study by Draper et al. (2012). 
The importance of correctly specifying random errors and biases is a major conceptual challenge in the optimization of distributed assimilation systems. Bias mitigation has become a regular part of most soil moisture data assimilation systems (Reichle and Koster 2004; Drusch et al. 2005; Kumar et al. 2012; Sahoo et al. 2013), and random error specifications for soil moisture data assimilation have been studied through adaptive filtering (Crow and van Loon 2006; Reichle et al. 2008).

Another idea with potential benefit is multi-sensor assimilation for soil moisture estimation. As an example, Draper et al. (2012) showed how both active (ASCAT) and passive (AMSR-E) microwave retrievals can contribute to a similar improvement in assimilation results. Combining improved precipitation data with soil moisture retrieval assimilation (Liu et al. 2011) and combining discharge (Pauwels and De Lannoy 2006), temperature or LAI with soil moisture assimilation are other avenues that have been exploited for hydrological assimilation.

As already indicated for single-column applications, a major conceptual problem is the direct assimilation of brightness temperatures $\left(T_{\mathrm{b}}\right)$ or backscatter observations from satellite missions for soil moisture estimation. Reichle et al. (2001a, b) presented pioneering studies with a 3-D variational scheme to assimilate and disaggregate synthetic or real brightness temperatures over the SGP97 study area, while Margulis et al. (2002) used an EnKF and Dunne and Entekhabi (2006) compared an EnKF with an EnKS for the same $T_{\mathrm{b}}$ assimilation problem. Walker et al. (2002) also assimilated $T_{\mathrm{b}}$ directly, but from SMMR and using an EKF over Australia. Using a variational scheme, and with inclusion of both a land surface temperature and microwave brightness temperature observation operator, Barrett and Renzullo (2009) showed that both thermal (AVHRR) and microwave (AMSRE) satellite observations can provide effective observational constraints on the modelled profile and on surface soil moisture. There are only a few studies on spatially distributed backscatter assimilation, but in a recent OSSE using an EnKF, Flores et al. (2012) showed the potential of the L-band radar information expected from the future SMAP mission.

For snow, spatially distributed assimilation studies include snow cover area (or snow cover fraction) and snow water equivalent (SWE) assimilation. A correct specification of the snow-covered area is important to represent feedbacks from the land to the atmosphere, while a good estimate of the actual amount of snow in the snowpack is of crucial importance for flood, drought and discharge predictions (He et al. 2012). Snow cover observations are typically fine-scale visible/near infrared observations that are only available in cloud-free areas, while SWE measurements are typically more inaccurate retrievals from $T_{\mathrm{b}}$ observations at a coarse scale (see Table 1). It can be expected that multi-sensor assimilation could help to further snow estimation (De Lannoy et al. 2012).

Because of its binary nature, snow cover in terms of the presence or absence of snow cannot be assimilated with filters that rely on continuous variables. Instead, rule-based algorithms have been proposed (Rodell and Houser 2004; Zaitchik and Rodell 2009; Roy et al. 2010). However, the snow cover fraction (SCF) is a more continuous variable that has been assimilated with KF-based algorithms (Clark et al. 2006; Su et al. 2008; De Lannoy et al. 2012). When assimilating SCF with a Kalman filter, there is a need to relate SCF to the actual SWE state variable through an observation operator, often defined as a snow depletion curve. It is also possible to use visible/near infrared snow albedo observations to update snow parameters such as grain size (Dumont et al. 2012).

The two dominant conceptual problems with satellite-based SWE assimilation are the coarse-scale nature and high uncertainty of the measurements. Initial attempts to assimilate SMMR or AMSR-E SWE retrievals only yielded marginal success (Andreadis and Lettenmaier 2006; Dong et al. 2007), because of retrieval errors due to signal saturation, 
presence of liquid water in the snowpack and multiple other factors. To address the coarsescale issue, De Lannoy et al. (2010) proposed several 3-D filter options to disaggregate SWE data and propagate data from observed swaths to unobserved regions. These techniques showed great benefit in a synthetic data study. When using real AMSR-E retrievals (De Lannoy et al. 2012), and with bias mitigation through re-scaling added to the system, the assimilation analyses were affected by a lack of a realistic interannual signal in the retrievals.

To address the problems with SWE retrieval accuracy, the potential of direct radiance assimilation has been investigated (Durand and Margulis 2006; Andreadis et al. 2008; Durand et al. 2009; DeChant and Moradkhani 2010). However, these efforts rely on a good description of the snowpack in the land surface model, which is not always available for large-scale applications. To address this, Forman et al. (2013) developed an artificial neural network as a computationally attractive forward model in readiness for large-scale radiance assimilation. In preparation for the future SMAP mission, freeze-thaw assimilation (Bateni et al. 2013) has been investigated, because of its importance in understanding the carbon cycle.

The above studies update either snow or soil moisture separately. A major challenge for land data assimilation is making use of total water storage (TWS) observations from GRACE, which include soil moisture, snow and other water components at a very coarse scale (Table 1). Total water storage can be decomposed into soil and snow components and disaggregated to finer scales (Zaitchik et al. 2008; Su et al. 2010; Forman et al. 2012; Li et al. 2012; Reichle et al. 2013).

\subsection{Towards Operational Land Data Assimilation}

Land surface processes and their initialization are of crucial importance to address the challenge of seamless prediction from weather to seasonal and climate timescales (Palmer et al. 2008). It is well established that high skill in short- and medium-range forecasts of temperature and humidity over land requires proper initialization of soil moisture (Beljaars et al. 1996; Douville et al. 2000; Mahfouf et al. 2000; Drusch and Viterbo 2007; van den Hurk et al. 2008). A similar impact from soil moisture has been established for seasonal forecasts (Koster et al. 2004a, b, 2011; Weisheimer et al. 2011). Initialization of snow conditions also has a significant impact on forecast accuracy at weather timescales (Brasnett 1999; Drusch et al. 2004). Operational land data assimilation has initially focused on ingesting precipitation observations (e.g., Saha et al. 2010; Reichle et al. 2011), but improved snow and soil moisture state updates are now emerging, as documented, for example, for the ECMWF Integrated Forecasting System by de Rosnay et al. (2012a).

An unprecedented operational land data assimilation product will be provided by the Global Modeling and Assimilation Office (NASA GMAO) in the form of a level 4 satellitebased soil moisture product (Reichle et al. 2012; De Lannoy et al. 2013). The assimilation of SMAP brightness temperatures into the Goddard Earth Observing System land surface model will yield a global root zone soil moisture product.

\section{Conceptual Problems and Key Challenges}

To summarize, the conceptual problems in our understanding of the hydrological cycle over land can be grouped by observing, modelling and data assimilation systems. These are outlined below. 


\subsection{Assimilated Observations}

- To be useful for model development and assimilation, the dominant modes (in space and time) of the land system must be sampled;

- To be efficient for state updating, observations need to be available at a reasonable time interval to capture short-term dynamical variations (cf. the importance of satellite overpass frequency; Walker and Houser 2004; Pan and Wood 2010);

- Observations must be collected in long enough historical records to identify long-term, climatological, statistics for bias mitigation (Reichle and Koster 2004) or trend identification;

- Observations need to be sampled at different spatial scales to capture both local and global processes;

- There is a need to have a reasonable signal-to-noise ratio (e.g., SMAP's target of brightness temperature uncertainty is $1.3 \mathrm{~K}$; Entekhabi et al. 2010a), and an uncertainty in the error description appropriate for scientific studies;

- There is a need to relate observations to key system state variables, that is, there needs to be system observability.

\subsection{Forward and Retrieval Models, with Particular Reference to Radiances} and Backscatter Processes

- To achieve appropriate retrieval accuracy, there is a need to use advanced methods to describe physical processes in radiative transfer models (RTMs);

- When assimilating radiances at large scales (e.g., from microwave sensors), there is a need for calibration of RTMs (De Lannoy et al. 2013; Forman et al. 2013).

\subsection{Land Surface Models}

- There is a need to use advanced methods to describe physical processes (this limits structural uncertainty) and couple land surface models with models describing more specialized processes such as run-off routing, dynamic vegetation or snow (Pauwels et al. 2006);

- There is a need for consistent global parameter datasets to limit predictive uncertainty due to parameter uncertainty;

- There is a need for high-quality forcing data (this limits input uncertainty), mainly for precipitation (Maggioni et al. 2011; Reichle et al. 2011).

\subsection{Data Assimilation Challenges}

- There is a need to fill in the spatial and temporal gaps in observations (Reichle and Koster 2003; De Lannoy et al. 2012);

- There is a need to disaggregate data in space and time and into their individual components (Forman et al. 2012; Reichle et al. 2013);

- There is a need to ingest directly radiances or backscatter information (as opposed to retrievals) to avoid inconsistencies between auxiliary information in retrievals and land surface models (Crow and Wood 2003; Durand et al. 2009; Flores et al. 2012); 
- There is a need to exploit the simultaneous use of multiple sensors (Pan et al. 2008; Draper et al. 2012) and explore the capabilities of new sensors (Andreadis et al. 2007; Durand et al. 2008);

- There is a need to combine state and input (forcing) information with parameter updates (Moradkhani et al. 2005b; Liu et al. 2011; Vrugt et al. 2012);

- There is a need to explore advanced filtering techniques, for example, the use of the particle filter to account for non-Gaussian errors (Plaza et al. 2012);

- There is a need to improve the representation of observation and forecast errors, and to specify biases in observational and model information (De Lannoy et al. 2007b; Crow and Reichle 2008; Reichle et al. 2008; De Lannoy et al. 2009; Crow and van den Berg 2010);

- There is a need to preserve water balance in the land system (Pan and Wood 2006; Yilmaz et al. 2011) and draw lessons from the information in the assimilation increments;

- There is a need to have access to adequate computational resources.

\subsection{Validation}

- Needs ground observations with substantial spatial and temporal coverage;

- Needs tools to address scaling and representativeness errors (Crow et al. 2012);

- Needs appropriate and effective validation metrics (Entekhabi et al. 2010b).

\section{Conclusions}

To understand the hydrological cycle over land, we need to make observations and develop models that encapsulate our understanding. These models have a basis on the information gathered from observations, as well as on previous experience, and are used to project our understanding into the future by making predictions. A crucial element in this procedure is confronting models with observations. Data assimilation, which combines observational and model information, provides an objective method to confront models against observations and add value to both the model and the observations. Data assimilation adds value to observations by filling the gaps between them and adds value to models by constraining them with observations. In this paper, we touch on the main conceptual problems that limit a full integration of land surface models and observations by reviewing progress in land surface data assimilation research over the last decade.

Collectively, the advent of new satellite missions, the increasing attention to forecast uncertainty due to errors in the land surface model structure, parameters and input, and the development of advanced assimilation techniques will eventually close the largest gaps in our understanding of the hydrological cycle over land.

Acknowledgments This paper arose from the International Space Science Institute (ISSI) workshop "The Earth's Hydrological Cycle", held at ISSI, Bern, Switzerland, on 6-10 February 2012. A NILU internal project supported WAL. Thanks to Alexandra Griesfeller for providing Fig. 2.

Open Access This article is distributed under the terms of the Creative Commons Attribution License which permits any use, distribution, and reproduction in any medium, provided the original author(s) and the source are credited. 


\section{Appendix: Sensor acronyms}

$\begin{array}{ll}\text { AACE } & \text { Australian Airborne Cal/Val Experiments (for SMOS) } \\ \text { AMSR } & \text { Advanced Microwave Sounding Radiometer on EOS Aqua } \\ \text { ASCAT } & \text { Advanced SCATterometer } \\ \text { ASTER } & \text { Advanced Spaceborne Thermal Emission and reflection Radiometer } \\ \text { AVHRR } & \text { Advanced Very High Resolution Radiometer } \\ \text { CONAE } & \text { COmisión Nacional de Actividades Espaciales (National Space } \\ & \text { Activities Commission) -Argentina Space Agency } \\ \text { CoReH2O } & \text { COld REgions Hydrology high-resolution Observatory } \\ \text { ERS } & \text { European Research Satellite } \\ \text { ESA } & \text { European Space Agency } \\ \text { GOES } & \text { Geostationary Operational Environmental Satellite } \\ \text { GPM } & \text { Global Precipitation Measurement } \\ \text { GRACE } & \text { Gravity Recovery And Climate Experiment } \\ \text { JERS } & \text { Japanese Earth Resources Satellite } \\ \text { MODIS } & \text { MODerate resolution Imaging Spectroradiometer } \\ \text { MUREX } & \text { Monitoring of the Usable Reservoir EXperiment } \\ \text { NASA } & \text { National Aeronautics and Space Administration } \\ \text { SCLP } & \text { Snow and Cold Land Process } \\ \text { SMAP } & \text { Soil Moisture Active and Passive } \\ \text { SMMR } & \text { Scanning Multichannel Microwave Radiometer } \\ \text { SMOS } & \text { Soil Moisture and Ocean Salinity } \\ \text { SMOSMANIA } & \text { Soil Moisture Observing System-Meteorological Automatic Network } \\ & \text { Integrated Application } \\ \text { SMOSREX } & \text { Surface MOnitoring of the Soil Reservoir EXperiment } \\ \text { SSM/I } & \text { Special Sensor Microwave Imager } \\ \text { SWOT } & \text { Surface Water Ocean Topography } \\ \text { TRMM } & \text { Tropical Rainfall Measuring Mission } \\ \end{array}$

\section{References}

Adams DKRM, Fernandes S, Kursinski ER, Maia JM, Sapucci LF, Machado LAT, Vitorello I, Galera Monico JF, Holub KL, Gutman S, Filizola N, Bennett RA (2011) A dense GNSS meteorological network for observing deep convection in the Amazon. Atmos Sci Lett 12. doi:10.1002/asl.312

Al Bitar A, Leroux D, Kerr YH, Merlin O, Richaume P, Sahoo A, Wood EF (2012) Evaluation of SMOS soil moisture products over continental U.S. using the SCAN/SNOTEL network. IEEE Trans Geosci Remote Sens 50:1572-1586

Albergel C, Rüdiger C, Carrer D, Calvet J-C, Fritz N, Naeimi V, Bartalis Z, Hasenauer S (2009) An evaluation of ASCAT surface soil moisture products with in situ observations in Southwestern France. Hydrol Earth Syst Sci 13:115-124

Albergel C, Calvet J-C, Mahfouf J-F, Rüdiger C, Barbu AL, Lafont S, Roujean J-L, Walker JP, Crapeau M, Wigneron J-P (2010) Monitoring of water and carbon fluxes using a land data assimilation system: a case study for southwestern France. Hydrol Earth Syst Sci 14:1109-1124

Andreadis KM, Lettenmaier DP (2006) Assimilating remotely sensed snow observation into a macroscale hydrology model. Adv Water Resour 29:872-886

Andreadis K, Clark E, Lettenmaier D, Alsdorf D (2007) Prospects for river discharge and depth estimation through assimilation of swath-altimetry into a raster-based hydrodynamics model. Geophys Res Lett 34:L10403 
Andreadis KM, Liang D, Tsang L, Lettenmaier DP, Josberger EG (2008) Characterization of errors in a coupled snow hydrology microwave emission model. J Hydrometeorol 9:149-164

Arsenault K, Houser P, Dirmeyer P, De Lannoy G (2013) Impacts of snow cover fraction data assimilation on modeled energy and moisture budgets. J Geophys Res (in press)

Aubert D, Loumagne C, Oudin L (2003) Sequential assimilation of soil moisture and streamflow data into a conceptual rainfall-runoff model. J Hydrol 280:145-161

Balsamo G, Bouyssel F, Noilhan J (2004) A simplified bi-dimensional variational analysis of soil moisture from screen-level observations in a mesoscale numerical weather-prediction model. Q J R Meteorol Soc 130:895-915

Balsamo G, Bélair S, Deblonde G (2006) A global root-zone soil moisture analysis using simulated L-band brightness temperature in preparation for the hydros satellite mission. J Hydrometeorol 7:1126-1146

Balsamo G, Viterbo P, Beljaars A, van den Hurk B, Hirschi M, Betts AK, Scipal K (2009) A revised hydrology for the ECMWF model: verification from field site to terrestrial water storage and impact in the integrated forecast system. J Hydrometeorol 10. doi:10.1175/2008JHM1068.1

Bannister RN (2008a) A review of forecast error covariance statistics in atmospheric variational data assimilation. I: characteristics and measurements of forecast error covariances. Q J R Meteorol Soc 134:1951-1970

Bannister RN (2008b) A review of forecast error covariance statistics in atmospheric variational data assimilation. II: modelling the forecast error covariances. Q J R Meteorol Soc 134:1971-1996

Barrett D, Renzullo LJ (2009) On the efficacy of combining thermal and microwave satellite data as observational constraints for root-zone soil moisture estimation. J Hydrometeorol 10:1109-1127

Bartalis Z, Wagner W, Naeimi V, Hasenauer S, Scipal K, Bonekamp H, Figa J, Anderson C (2007) Initial soil moisture retrievals from the METOP-A advanced Scatterometer (ASCAT). Geophys Res Lett 34:L20401. doi:10.1029/2007GL031088

Bateni SM, Huang C, Margulis SA, Podest E, McDonald K (2013) Feasibility of characterizing snowpack and the freeze-thaw state of underlying soil using multifrequency active/passive microwave data. IEEE Trans Geosci Remote Sens. doi:10.1109/TGRS.2012.2229466

Beljaars A, Viterbo P, Miller M, Betts A (1996) The anomalous rainfall over the United States during July 1993: sensitivity to land surface parameterization and soil anomalies. Mon Weather Rev 124:362-383

Best MJ, Pryor M, Clark DB, Rooney GG, Essery RLH, Ménard CB, Edwards JM, Hendry MA, Porson A, Gedney N, Mercado LM, Sitch S, Blyth E, Boucher O, Cox PM, Grimmond CSB, Harding RJ (2011) The Joint UK Land Environment Simulator (JULES), model description-part 1: energy and water fluxes. Geosci Model Dev 4:677-699

Beven K (1989) Changing ideas in hydrology: the case of physically-based models. J Hydrol 105:157-172

Beven BJ, Kirkby MJ (1979) A physically-based variable contributing area model of basin hydrology. Hydrol Sci Bull 24:43-69

Biancamaria S, Durand M, Andreadis KM, Bates PD, Boone A, Mognard NM, Rodríguez E, Alsdorf DE, Lettenmaier DP, Clark EA (2010) Assimilation of virtual wide swath altimetry to improve Arctic river modelling. Remote Sens Environ. doi:10.1016/j.rse.2010.09.008

Bircher S, Balling JE, Skou N, Kerr YH (2012) Validation of SMOS brightness temperatures during the HOBE airborne campaign, Western Denmark. IEEE Trans Geosci Remote Sens 50:1468-1482

Boni G, Entekhabi D, Castelli F (2001) Land data assimilation with satellite measurements for the estimation of surface energy balance components and surface control on evaporation. Water Resour Res $37: 1713-1722$

Boone A (1999) Modelisation des processus hydrologiques dans le schema de surface ISBA: Inclusion d'un reservoir hydrologique, du gel et modelisation de la neige, $\mathrm{PhD}$ thesis, University Paul Sabatier, Toulouse, France, 2000, 252 pp

Bosilovich MG, Radakovich JD, Silva AD, Todling R, Verter F (2007) Skin temperature analysis and bias correction in a coupled land-atmosphere data assimilation system. J Meteorol Soc Jpn 85A:205-228

Boulet G, Kerr Y, Chehbouni A (2002) Deriving catchment-scale water and energy balance parameters using data assimilation based on extended Kalman filtering. Hydrol Sci J des Sci Hydrol 47:449-467

Bouttier F, Courtier P (1999) Data assimilation concepts and methods. ECMWF training notes, March 1999, available from http://www.ecmwf.int

Branstetter ML, Erickson DJ III (2003) Continental runoff dynamics in the Community Climate System Model 2 (CCSM2) control simulation. J Geophys Res 108:4550. doi:10.1029/2002JD003212

Brasnett B (1999) A global analysis of snow depth for numerical weather prediction. J Appl Meteorol 38:726-740

Calvet J-C, Noilhan J, Bessemoulin P (1998) Retrieving the root-zone soil moisture from surface soil moisture or temperature estimates: a feasibility study based on field measurements. J Appl Meteorol $37: 371-386$ 
Calvet J-C, Fritz N, Froissard F, Suquia D, Petitpa A, Piguet B (2007) In-situ soil moisture observations for the CAL/VAL of SMOS: the SMOSMANIA network. International geoscience and remote sensing symposium, IGARSS, 23-28 July 2007, Barcelona, Spain, pp 1196-1199. doi:10.1109/ IGARSS.2007.4423019

Camporese M, Paniconi C, Putti M, Salandin P (2009) Ensemble Kalman filter data assimilation for a process-based catchment scale model of surface and subsurface flow. Water Resour Res 45:W10421

Caparrini F, Castelli F, Entekhabi D (2004) Variational estimation of soil and vegetation turbulent transfer and heat flux parameters from sequences of multisensor imagery. Water Resour Res 40:W12515.1W12515.15

Castelli F, Entekhabi D, Caporali E (1999) Estimation of surface heat flux and an index of soil moisture using adjoint-state surface energy balance. Water Resour Res 35:3115-3125

Castro R, Gutierrez A, Barbosa J (2012) A first set of techniques to detect radio frequency interferences and mitigate their impact on SMOS data. IEEE Trans Geosci Remote Sens 50:1440-1447

Clark M, Vrugt J (2006) Unraveling uncertainties in hydrologic model calibration: addressing the problem of compensatory parameters. Geophys Res Lett 33:L06406.1-L06406.5

Clark MP, Slater AG, Barrett AP, Hay LE, McCabe GJ, Rajagopalan B, Leavesley GH (2006) Assimilation of snow covered area information into hydrologic and land-surface models. Adv Water Resour 29:1209-1221

Clark DB, Mercado LM, Sitch S, Jones CD, Gedney N, Best MJ, Pryor M, Rooney GG, Essery RLH, Blyth E, Boucher O, Harding RJ, Huntingford C, Cox PM (2011a) The Joint UK Land Environment Simulator (JULES), model description-part 2: carbon fluxes and vegetation dynamics. Geosci Model Dev 4:701-722

Clark MP, Hendrikx L, Slater AG, Kavetski D, Anderson B, Cullen NJ, Kerr T, Hreinsson EÖ, Woods RA (2011b) Representing spatial variability of snow water equivalent in hydrologic and land-surface models: a review. Water Resour Res 47:W07539

Crosson WL, Laymon CA, Inguva R, Schamschula MP (2002) Assimilating remote sensing data in a surface flux-soil moisture model. Hydrol Process 16:1645-1662

Crow W (2003) Correcting land surface model predictions for the impact of temporally sparse rainfall rate measurements using an ensemble Kalman filter and surface brightness temperature observations. J Hydrometeorol 4:960-973

Crow WT (2007) A novel method for quantifying value in spaceborne soil moisture retrievals. J Hydrometeorol 8:56-67. doi:10.1175/JHM553.1

Crow WT, Bolten JD (2007) Estimating precipitation errors using spaceborne surface soil moisture retrievals. Geophys Res Lett 34:L08403

Crow WT, Reichle RH (2008) Comparison of adaptive filtering techniques for land surface data assimilation. Water Resour Res 44:W08423. doi:10.1029/2008WR006883

Crow WT, Ryu D (2009) A new data assimilation approach for improving runoff prediction using remotely sensed soil moisture retrievals. Hydrol Earth Syst Sci 13:1-16

Crow WT, van den Berg J (2010) An improved approach for estimating observation and model error parameters in soil moisture data assimilation. Water Resour Res 46:W12519

Crow WT, van Loon E (2006) Impact of incorrect model error assessment on the sequential assimilation of remotely sensed surface soil moisture. J Hydrometeorol 7:421-432

Crow WT, Wood EF (2003) The assimilation of remotely sensed soil brightness temperature imagery into a land surface model using ensemble Kalman filtering: a case study based on ESTAR measurements during SGP97. Adv Water Resour 26:137-149

Crow WT, Zhan X (2007) Continental-scale evaluation of remotely sensed soil moisture products. IEEE Geosci Remote Sens Lett 4:451-455. doi:10.1109/LGRS.2007.896533

Crow WT, Miralles DG, Cosh MH (2010) A quasi-global evaluation system for satellite-based surface soil moisture retrievals. IEEE Geosci Remote Sens Lett 48:2516-2527

Crow WT, Berg AA, Cosh MH, Loew A, Mohanty BP, Panciera R, de Rosnay P, Ryu D, Walker JP (2012) Upscaling sparse ground-based soil moisture observations for the validation of coarse-resolution satellite soil moisture products. Rev Geophys Res 50:RG2002. doi:10.1029/2011RG000372

dall'Amico JT, Schlenz F, Loew A, Mauser W (2012) First results of SMOS soil moisture validation in the Upper Danube catchment. IEEE Trans Geosci Remote Sens 50:1507-1516

Davenport I, Sandells M, Gurney R (2012) The effects of variation in snow properties on passive microwave snow mass estimation. Remote Sens Environ 118:168-175

De Lannoy GJM, Houser PR, Pauwels VRN, Verhoest NEC (2006) Assessment of model uncertainty for soil moisture through ensemble verification. J Geophys Res 111:D10101.1-D10101.18. doi: 10.1029/2005JD006367 
De Lannoy GJM, Houser PR, Pauwels VRN, Verhoest NEC (2007a) State and bias estimation for soil moisture profiles by an ensemble Kalman filter: effect of assimilation depth and frequency. Water Resour Res 43:W06401. doi:10.1029/2006WR005100

De Lannoy GJM, Reichle RH, Houser PR, Pauwels VRN, Verhoest NEC (2007b) Correcting for forecast bias in soil moisture assimilation with the ensemble Kalman filter. Water Resour Res 43:W09410. doi: 10.1029/2006WR00544

De Lannoy GJM, Houser PR, Verhoest NEC, Pauwels VRN (2009) Adaptive soil moisture profile filtering for horizontal information propagation in the independent column-based CLM2.0. J Hydrometeorol 10:766-779

De Lannoy GJM, Reichle RH, Houser PR, Arsenault KR, Pauwels VRN, Verhoest NEC (2010) Satellitescale snow water equivalent assimilation into a high-resolution land surface model. J Hydrometeorol 11:352-369. doi:10.1175/2009JHM1194.1

De Lannoy GJM, Reichle R, Arsenault K, Houser P, Kumar S, Verhoest N, Pauwels V (2012) Multiscale assimilation of advanced microwave scanning radiometer-EOS snow water equivalent and moderate resolution imaging spectroradiometer snow cover fraction observations in northern Colorado. Water Resour Res 48:W01522

De Lannoy GJM, Reichle RH, Pauwels VRN (2013) Global calibration of the GEOS-5 L-band microwave radiative transfer model over land using SMOS observations. J Hydrometeorol (in press)

de Rosnay P, Calvet J-C, Kerr Y, Wigneron J-P, Lemaître F et al (2006) SMOSREX: a long term field campaign experiment for soil moisture and land surface processes remote sensing. Remote Sens Environ 102(377-389):2006

de Rosnay P, Balsamo G, Albergel C, Muñoz-Sabater J, Isaksen L (2012a) Initialisation of land surface variables for numerical weather prediction. Surv Geophys. doi:10.1007/s10712-012-9207-X

de Rosnay PD, Drusch M, Vasiljevic D, Balsamo G, Albergel C, Isaksen L (2012b) A simplified extended Kalman filter for the global operational soil moisture analysis at ECMWF. Q J R Meteorol Soc. doi: 10.1002/qj.2023

Deardorff JW (1977) A parameterization of ground surface moisture content for use in atmospheric prediction models. J Appl Meteorol 16:1182-1185

DeChant C, Moradkhani H (2010) Radiance data assimilation for operational snow and streamflow forecasting. Adv Water Resour 34:351-364

Decharme B, Douville H (2006) Introduction of a sub-grid hydrology in the ISBA land surface model. Clim Dyn 26:65-78

Decharme B, Douville H (2007) Global validation of the ISBA sub-grid hydrology. Clim Dyn 29:21-37

Decharme B, Douville H, Boone A, Habets F, Noilhan J (2006) Impact of an exponential profile of saturated hydraulic conductivity within the ISBA LSM: simulations over the Rhône basin. J Hydrometeorol 7:61-80

Dee DP (2005) Bias and data assimilation. Q J R Meteorol Soc 131:3323-3343

Déry SJ, Salomonson VV, Stieglitz M, Hall DK, Appel I (2005) An approach to using snow areal depletion curves inferred from MODIS and its application to land surface modelling in Alaska. Hydrol Process 19:2755-2774

Desroziers G, Berre L, Chapnik B, Poli P (2005) A simple method to diagnose and adapt observation and background errors. Q J R Meteorol Soc 131:3385-3396

Dharssi I, Bovis KJ, Macpherson B, Jones CP (2011) Operational assimilation of ASCAT surface soil wetness at the Met Office. Hydrol Earth Syst Sci 15:2729-2746

Dirmeyer P (2000) Using a global soil wetness dataset to improve seasonal climate simulation. J Clim 13:2900-2921

Dong J, Walker JP, Houser PR, Sun C (2007) Scanning multichannel microwave radiometer snow water equivalent assimilation. J Geophys Res 112:D07108. doi:10.1029/2006JD007209

Dorigo W, Scipal K, Parinussa RM, Liu YY, Wagner W, de Jeu RAM, Naeimi V (2010) Error characterization of global active and passive microwave soil moisture data sets. Hydrol Earth Syst Sci 14:2605-2616

Douville H, Viterbo P, Mahfouf J-F, Beljaars ACM (2000) Evaluation of optimal interpolation and nudging techniques for soil moisture analysis using FIFE data. Mon Weather Rev 128:1733-1756

Draper CS, Mahfouf J-F, Walker J (2009) An EKF assimilation of AMSR-E soil moisture into the ISBA land surface scheme. J Geophys Res 114:D20104.1-D20104.13. doi:10.1029/2008JD011650

Draper C, Mahfouf J-F, Walker J (2011) Root zone soil moisture from the assimilation of screen-level variables and remotely sensed soil moisture. J Geophys Res 116:D02127

Draper CS, Reichle RH, De Lannoy GJM, Liu Q (2012) Assimilation of passive and active microwave soil moisture retrievals. Geophys Res Lett 39:L04401 
Drusch M (2007) Initializing numerical weather prediction models with satellite surface soil moisture: Data assimilation experiments with ECMWF's integrated forecast system and the TMI soil moisture data set. J Geophys Res 112. doi:10.1029/2006JD007478

Drusch M, Viterbo P (2007) Assimilation of screen-level variables in ECMWF's integrated forecast system: a study on the impact on the forecast quality and analyzed soil moisture. Mon Weather Rev 135:300-314

Drusch M, Vasilievic D, Viterbo P (2004) ECMWF's global snow analysis: assessment and revision based on satellite observations. J Appl Meteorol 43:1282-1294

Drusch M, Wood EF, Gao H (2005) Observation operators for the direct assimilation of TRMM microwave imager retrieved soil moisture. J Geophys Res 32:L15403.1-L15403.4

Duan Q, Sorooshian S, Gupta VK (1992) Effective and efficient global optimization for conceptual rainfallrunoff models. Water Resour Res 28:1015-1031

Dumedah G, Berg AA, Wineberg M (2011) An integrated framework for a joint assimilation of brightness temperature and soil moisture using the nondominated sorting genetic algorithm II. J Hydrometeorol 12:1596-1609

Dumont M, Durand Y, Arnaud Y, Six D (2012) Variational assimilation of albedo in a snowpack model and reconstruction of the spatial mass-balance distribution of an alpine glacier. J Glaciol 58:151-164

Dunne S, Entekhabi D (2006) Land surface state and flux estimation using the ensemble Kalman smoother during the Southern Great Plains 1997 field experiment. Water Resour Res 42:W01407.1-W01407.15

Durand M, Margulis SA (2006) Feasibility test of multifrequency radiometric data assimilation to estimate snow water equivalent. J Hydrometeorol 7:443-457

Durand M, Margulis SA (2007) Correcting first-order errors in snow water equivalent estimates using a multifrequency, multiscale radiometric data assimilation scheme. J Geophys Res 112:D13121.1D13121.15

Durand M, Andreadis K, Alsdorf D, Lettenmaier D, Moller D, Wilson M (2008) Estimation of bathymetric depth and slope from data assimilation of swath altimetry into a hydrodynamic model. Geophys Res Lett 35:L20401

Durand M, Kim E, Margulis SA (2009) Radiance assimilation shows promise for snowpack characterization. Geophys Res Lett 36:L02503.1-L02503.5

Ek MB, Mitchell KE, Lin Y, Rogers E, Grunmann P, Koren V, Gayno G, Tarpley JD (2003) Implementation of Noah land surface model advances in the National Centers for Environmental Prediction operational mesoscale Eta model. J Geophys Res 108:8851. doi:10.1029/2002JD003296.0

Entekhabi D, Nakamura H, Njoku EG (1994) Solving the inverse problem for soil moisture and temperature profiles by sequential assimilation of multifrequency remotely sensed observations. IEEE Trans Geosci Remote Sens 32:438-448

Entekhabi D, Njoku EG, O’Neill PE, Kellogg KH, Crow WT, Edelstein WN, Entin JK, Goodman SD, Jackson TJ, Johnson J, Kimball J, Piepmeier JR, Koster RD, Martin N, McDonald KC, Moghaddam M, Moran S, Reichle R, Shi JC, Spencer MW, Thurman SW, Tsang L, Van Zyl J (2010a) The Soil Moisture Active and Passive (SMAP) mission. Proc IEEE 98:704-716

Entekhabi D, Reichle RH, Koster RD, Crow WT (2010b) Performance metrics for soil moisture retrievals and application requirements. J Hydrometeorol 11:832-840

Essery R, Pomeroy J (2004) Implications of spatial distributions of snow mass and melt rate for snow-cover depletion: theoretical considerations. Ann Glaciol 38:261-265

Evensen G (2003) The ensemble Kalman filter: theoretical formulation and practical implementation. Ocean Dyn 53:343-367

Famiglietti J, Wood E (1994) Multiscale modeling of spatially variable water and energy balance processes. Water Resour Res 30:3061-3078

Flores A, Bras RL, Entekhabi D (2012) Hydrologic data assimilation with a hillslope-scale resolving model and L-band radar observations: synthetic experiments with the ensemble Kalman filter. Water Resour Res 48:W08509

Forman BA, Reichle RH, Rodell M (2012) Assimilation of terrestrial water storage from GRACE in a snowdominated basin. Water Resour Res 48:W01507

Forman B, Reichle RH, Derksen C (2013) Estimating passive microwave brightness temperature over snowcovered land in North America using a land surface model and an artificial neural network. IEEE Trans Geosci Remote Sens (in press)

Francois C, Quesney A, Ottlé C (2003) Sequential assimilation of ERS-1 SAR data into a coupled land surface-hydrological model using an extended Kalman filter. J Hydrometeorol 4:473-487

Galantowicz JF, Entekhabi D, Njoku EG (1999) Tests of sequential data assimilation for retrieving profile soil moisture and temperature from observed L-band radiobrightness. IEEE Trans Geosci Remote Sens 37:1860-1870 
GCOS-107 (2006) Systematic observation requirements for satellite-based products for climate. Supplemental details to the satellite-based component of the "implementation plan for the global observing system for climate in support of the UNFCCC", GCOS-107, WMO/TD No. 1338, Sept 2006

Georgakakos KP, Baumer OW (1996) Measurement and utilization of on-site soil moisture data. J Hydrol 184:131-152

Ghent D, Kaduk J, Remedios J, Ard J, Balzter H (2010) Assimilation of land surface temperature into the land surface model JULES with an ensemble Kalman filter. J Geophys Res 115:D19112

Giustarini L, Matgen P, Hostache R, Montanari M, Plaza D, Pauwels V, De Lannoy G, De Keyser R, Pfister L, Hoffmann L, Savenije H (2011) Assimilating SAR-derived water level data into a flood models: a case study. Hydrol Earth Syst Sci 15:2349-2365

Günter A (2008) Improvement of global hydrological models using GRACE data. Surv Geophys 2008:375-397

Guo JCY (2006) Urban hydrology and hydraulic design. Water Resources Publications, LLC, Colorado

Gustafsson D et al (2004) Modeling water and heat balance of the Boreal landscape-comparison of forest and arable land in Scandinavia. J Appl Meteorol 43:1750-1767

Gutmann E, Small E (2010) A method for the determination of the hydraulic properties of soil from MODIS surface temperature for use in land-surface models. Water Resour Res 46:W06520

Han E, Merwade V, Heathman G (2012a) Application of data assimilation with the root zone water quality model for soil moisture profile estimation in the upper Cedar Creek, Indiana. Hydrol Process 26:1707-1719

Han X, Li X, Hendricks H, Vereecken H, Montzka C (2012b) Spatial horizontal correlation characteristics in the land data assimilation of soil moisture. Hydrol Earth Syst Sci 26:1349-1363

He M, Hogue T, Margulis S, Franz K (2012) An integrated uncertainty and ensemble-based data assimilation approach for improved operational streamflow predictions. Hydrol Earth Syst Sci 16:815-831

Hoeben R, Troch PA (2000) Assimilation of active microwave observation data for soil moisture profile estimation. Water Resour Res 36:2805-2819

Houser PR (2003) Land data assimilation systems. In: Swinbank R, Shuytaev V, Lahoz WA (eds) Data assimilation for the earth system. NATO science series: IV: earth and environmental sciences, vol 26. Kluwer, Dordrecht, pp 345-360

Houser PR, Shuttleworth WJ, Famiglietti JS, Gupta HV, Syed KH, Goodrich DC (1998) Integration of soil moisture remote sensing and hydrologic modeling using data assimilation. Water Resour Res 34:3405-3420

Houser PR, De Lannoy GJM, Walker JP (2010) Land surface data assimilation. In: Lahoz WA, Khattatov B, Ménard R (eds) Data assimilation: making sense of observations. Springer, Berlin, pp 549-597

Hurkmans R, Paniconi C, Troch PA (2006) Numerical assessment of a dynamical relaxation data assimilation scheme for a catchment hydrological model. Hydrol Process 20:549-563

Ines A, Mohanty B (2009) Near-surface soil moisture assimilation for quantifying effective soil hydraulic properties using genetic algorithms: 2. Using airborne remote sensing during SGP97 and SMEX02. Water Resour Res 45:W01408

IPCC (2007) Climate change 2007: the physical science basis. Contribution of working group I to the fourth assessment report, Intergovernmental Panel on Climate Change, Cambridge University Press, Cambridge

Jackson TJ, Bindlish R, Cosh MH, Zhao T, Starks PJ, Bosch DD, Seyfried M, Moran MS, Goodrich DC, Kerr YH, Leroux D (2012) Validation of Soil Moisture and Ocean Salinity (SMOS) soil moisture over watershed networks in the U.S. IEEE Trans Geosci Remote Sens 50:1530-1543

Jansson P-E, Karlberg L (2004) CoupModel, coupled heat and mass transfer model for soil-plant-atmosphere system. Royal Institute of Technology (web-based on line documentation with details on use of model). http://www.lwr.kth.se/Vara\%20Datorprogram/CoupModel/index.htm

Jansson C et al (2005) Preferential water flow in a glacial till soil. Nord Hydrol 36:1-11

Jansson P-E et al (2008) Simulated climate change impacts on fluxes of carbon in Norway spruce ecosystems along a climatic transect in Sweden. Biogeochemistry 89:81-94

Jarlan L, Balsamo G, Lafont S, Beljaars A, Calvet J-C, Mougin E (2008) Analysis of leaf area index in the ECMWF land surface model and impact on latent heat and carbon fluxes: application to West Africa. J Geophys Res 113:D24117

Jones A, Vukićević T, Vonder Haar T (2003) Variational data assimilation of soil moisture using 6 and $10 \mathrm{GHz}$ passive microwave data. J Hydrometeorol 5:213-229

Kainulainen J, Colliander A, Closa J, Martin-Neira M, Oliva R, Buenadicha G, Rubiales Alcaine P, Hakkarainen A, Hallikainen MT (2012) Radiometric performance of the SMOS reference radiometers-assessment after one year of operation. IEEE Trans Geosci Remote Sens 50:1367-1383

Kalma J, McVicar T, McCabe M (2008) Estimating land surface evaporation: a review of methods using remotely sensed surface temperature data. Surv Geophys 29:421-469 
Kalnay E (2003) Atmospheric modeling, data assimilation and predictability. Cambridge University Press, Cambridge

Kalnay E (2010) Ensemble Kalman filter: current status and potential. In: Lahoz WA, Khattatov B, Ménard R (eds) Data assimilation: making sense of observations. Springer, Berlin, pp 69-92

Karlberg L et al (2006) Modelling transpiration and growth in salinity-stressed tomato under different climatic conditions. Ecol Model 190:15-40

Karlberg L et al (2007) Modeling carbon turnover in five terrestrial ecosystems in the boreal zone using multiple criteria of acceptance. AMBIO J Hum Environ 35:448-458

Kerr YH, Waldteufel P, Wigneron J-P, Delwart S, Cabot F, Boutin J, Escorihuela M-J, Font J, Reul N, Gruhier C, Juglea SE, Drinkwater MR, Hahne A, Martín-Neira M, Mecklenburg S (2010) The SMOS mission: new tool for monitoring key elements of the global water cycle. Proc IEEE 98:666-687

Kerr YH, Font J, Martin-Neira M, Mecklenburg S (2012a) Introduction to the special issue on the ESA's Soil Moisture and Ocean Salinity Mission (SMOS) - instrument performance and first results. IEEE Trans Geosci Remote Sens 50:1351-1353

Kerr YH, Waldteufel P, Richaume P, Wigneron JP, Ferrazzoli P, Mahmoodi A, Al Bitar A, Cabot F, Gruhier C, Juglea SE, Leroux D, Mialon A, Delwart S (2012b) The SMOS soil moisture retrieval algorithm. IEEE Trans Geosci Remote Sens 50:1384-1403

Klemedtsson L et al (2008) Bayesian calibration method used to elucidate carbon turnover in forest on drained organic soil. Biogeochemistry 89:61-79

Kolberg S, Gottschalk L (2010) Interannual stability of grid cell snow depletion curves as estimated from MODIS images. Water Resour Res 46:W11555

Koster RD, Suarez MJ, Ducharne A, Stieglitz M, Kumar P (2000) A catchment-based approach to modeling land surface processes in a general circulation model 1. Model structure. J Geophys Res 105:24809-24822

Koster RD, Dirmeyer PA, Guo Z, Bonan G, Cox P, Gordon C, Kanae S, Kowalczyk E, Lawrence D, Liu P, Lu C, Malyshev S, McAvaney B, Mitchell K, Mocko D, Oki T, Oleson K, Pitman A, Sud Y, Taylor C, Verseghy D, Vasic R, Xue Y, Yamada T (2004a) Regions of strong coupling between soil moisture and precipitation. Science 305:1138-1140

Koster RD, Suarez M, Liu P, Jambor U, Berg A, Kistler M, Reichle R, Rodell M, Famiglietti J (2004b) Realistic initialization of land surface states: impacts on subseasonal forecast skill. J Hydrometeorol 5:1049-1063

Koster RD, Mahanama PP, Yamada TJ, Balsamo G, Berg AA, Boisserie M, Dirmeyer PA, Doblas-Reyes FJ, Drewitt G, Gordon CT, Guo Z, Jeong JH, Lee WS, Li Z, Luo L, Malyshev S, Merryfield WJ, Seneviratne SI, Stanelle T, van den Hurk BJJM, Vitart F, Wood EF (2011) The second phase of the global land-atmosphere coupling experiment: soil moisture contributions to subseasonal forecast skill. J Hydrometeorol 12:805-822

Kotecha JH, Djurić PM (2003) Gaussian particle filtering. IEEE Trans Signal Process 51:2592-2601

Kumar SV, Reichle RH, Peters-Lidard CD, Koster RD, Zhan X, Crow WT, Eylander JB, Houser PR (2008) A land surface data assimilation framework using the Land Information System: description and applications. Adv Water Resour 31:1419-1432

Kumar S, Reichle RH, Koster RD, Crow WT, Peters-Lidard CD (2009) Role of subsurface physics in the assimilation of surface soil moisture observations. J Hydrometeorol 10:1534-1547. doi: 10.1109/MC.2008.511

Kumar S, Reichle R, Harrison K, Peters-Lidard C, Yatheendradas S, Santanello J (2012) A comparison of methods for a priori bias correction in soil moisture data assimilation. Water Resour Res 48:W03515

Lacava T, Matgen P, Brocca L, Bittelli M, Pergola N, Moramarco T, Tramutoli V (2012) A first assessment of the SMOS soil moisture product with in situ and modeled data in Italy and Luxembourg. IEEE Trans Geosci Remote Sens 50:1612-1622

Lahoz WA, Khattatov B, Ménard R (eds) (2010a) Data assimilation: making sense of observations. Springer, Berlin

Lahoz WA, Walker S-E, Dammann D (2010b) The NILU SURFEX-EnKF land data assimilation system. NILU technical report TR 2/2010, Jan 2010. Available from http://www.nilu.no

Lakshmi V (2000) A simple surface temperature assimilation scheme for use in land surface models. Water Resour Res 36:3687-3700

Le Moigne P (2009) SURFEX scientific documentation. Note de Centre No. 87, Groupe de Meteorologie a Moyenne Exhell, Centre National de Recherches Météorologiques, Météo-France (SURFEX, V. 5, Issue 1). Available from http://hirlam.org/index.php?option=com_docman\&task=doc_downloads\& gid $=605 \&$ Itemid $=70$

Le Vine DM, Lagerloef GSE, Yueh S, Pellerano F, Dinnat E, Wentz F (2006) Aquarius mission technical overview. IGARSS 2006, pp 1678-1680 
Lee H, Seo D, Koren V (2011) Assimilation of streamflow and in situ soil moisture data into operational distributed hydrologic models: effects of uncertainties in the data and initial model soil moisture states. Adv Water Resour 34:1597-1615

Lewis P, Gómez-Dans J, Kaminski T, Settle J, Quaife T, Gobron N, Styles J, Berger M (2012) An earth observation land data assimilation system (EO-LDAS). Remote Sens Environ 120:219-235

Li J, Islam S (1999) On the estimation of soil moisture profile and surface fluxes partitioning from sequential assimilation of surface layer soil moisture. J Hydrol 220:86-103

Li B, Rodell M, Zaitchik BF, Reichle RH, Koster RD, van Dam TM (2012) Assimilation of GRACE terrestrial water storage into a land surface model: evaluation and potential value for drought monitoring in western and central Europe. J Hydrol 446-447:103-115

Liang X, Lettenmaier DP, Wood EF, Burges SJ (1994) A simple hydrologically based model of land surface water and energy fluxes for GSMs. J Geophys Res 99:14415-14428

Liston G, Hiemstra CA (2008) A simple data assimilation system for complex snow distributions (SnowAssim). J Hydrometeorol 9:989-1004

Liu Q, Reichle RH, Bindlish R, Cosh MH, Crow WT, de Jeu R, De Lannoy GJM, Huffman GJ, Jackson TJ (2011) The contributions of precipitation and soil moisture observations to the skill of soil moisture estimates in a land data assimilation system. J Hydrometeorol 12:750-765

Lo M, Famiglietti JS, Yeh PJ, Syed TH (2010) Improving parameter estimation and water table depth simulation in a land surface model using GRACE water storage and estimated base flow data. Water Resour Res 46:W05517

Loew A, Mauser W (2008) Inverse modeling of soil characteristics from surface soil moisture observations: potential and limitations. Hydrol Earth Syst Sci 5:95-145

Loew A, Schwank M, Schlenz F (2009) Assimilation of an L-band microwave soil moisture proxy to compensate for uncertainties in precipitation data. TGRS 47:2606-2616

Loth B, Graf H-F, Oberhuber JM (1993) Snow cover model for global climate simulations. J Geophys Res 98:10451-10464

Lynch-Stieglitz M (1994) The development and validation of a simple snow model for the GISS GCM. J Clim 7:1842-1855

Mackaro S, McNider R, Pour Biazar A (2011) Some physical and computational issues in land surface data assimilation of satellite skin temperatures. Pure Appl Geophys 167:1303-1458

McLaughlin D (2002) An integrated approach to hydrologic data assimilation: interpolation, smoothing, and filtering. Adv Water Resour 25:1275-1286

Madsen H (2003) Parameter estimation in distributed hydrological catchment modelling using automatic calibration with multiple objectives. Adv Water Resour 26:205-216

Maggioni V, Reichle R, Emmanouil A (2011) The effect of satellite rainfall error modeling on soil moisture prediction uncertainty. J Hydrometeorol 12:413-428

Mahfouf J-F (2010) Assimilation of satellite-derived soil moisture from ASCAT in a limited-area NWP model. Q J R Meteorol Soc 136:784-798

Mahfouf J-F, Bliznak V (2011) Combined assimilation of screen-level observations and radar-derived precipitation for soil moisture analysis. Q J R Meteorol Soc 137:709-722

Mahfouf J-F, Noilhan J (1996) Inclusion of gravitational drainage in a land surface scheme based on the force restore method. J Appl Meteorol 35:987-992

Mahfouf J-F, Viterbo P, Douville H, Beljaars A, Saarinen S (2000) A revised land surface analysis scheme in the integrated forecasting system. ECMWF Newsl 88:8-13

Mahfouf J-F, Bergaoui K, Draper C, Bouyssel C, Taillefer F, Taseva L (2009) A comparison of two off-line soil analysis schemes for assimilation of screen-level observations. J Geophys Res 114:D08105

Margulis SA, McLaughlin D, Entekhabi D, Dunne S (2002) Land data assimilation of soil moisture using measurements from the Southern Great Plains 1997 field experiment. Water Resour Res 38:35.1-35.18

Marzahn P, Ludwig R (2009) On the derivation of soil surface roughness from multi parametric PolSAR data and its potential for hydrological modeling. Hydrol Earth Syst Sci 13:381-394

Matgen P, Montanari M, Hostache R, Pfister L, Hoffmann L, Plaza D, Pauwels V, De Lannoy G, De Keyser R, Savenije H (2010) Towards the sequential assimilation of SAR-derived water stages into hydraulic models using the particle filter: proof of concept. Hydrol Earth Syst Sci 14:1773-1785

Mattar C, Wigneron J-P, Sobrino JA, Novello N, Calvet JC, Albergel C, Richaume P, Mialon A, Guyon D, Jimenez-Munoz JC, Kerr Y (2012) A combined optical-microwave method to retrieve soil moisture over vegetated areas. IEEE Trans Geosci Remote Sens 50:1404-1413

Mecklenburg S, Drusch M, Kerr YH, Font J, Martin-Neira M, Delwart S, Buenadicha G, Reul N, DaganzoEusebio E, Oliva R, Crapolicchio R (2012) ESA's Soil Moisture and Ocean Salinity Mission: mission performance and operations. IEEE Trans Geosci Remote Sens 50:1354-1366 
Ménard R (2010) Bias estimation. In: Lahoz WA, Khattatov B, Ménard R (eds) Data assimilation: making sense of observations. Springer, Berlin, pp 113-135

Meng CL, Li Z-L, Zhan X, Shi JC, Liu CY (2009) Land surface temperature data assimilation and its impact on evapotranspiration estimates from the common land model. Water Resour Res 45:W02421

Merlin O, Rüdiger C, Al Bitar A, Richaume P, Walker JP, Kerr YH (2012) Disaggregation of SMOS soil moisture in Southeastern Australia. IEEE Trans Geosci Remote Sens 50:1556-1571

Mialon A, Wigneron J-P, de Rosnay P, Escorihuela MJ, Kerr YH (2012) Evaluating the L-MEB model from long-term microwave measurements over a rough field, SMOSREX 2006. IEEE Trans Geosci Remote Sens 50:1458-1467

Misra S, Ruf CS (2012) Analysis of radio frequency interference detection algorithms in the angular domain for SMOS. IEEE Trans Geosci Remote Sens 50:1448-1457

Monsivais-Huerteroet A, Graham W, Judge J, Agrawal D (2010) Effect of simultaneous state-parameter estimation and forcing uncertainties on root-zone soil moisture for dynamic vegetation using EnKf. Adv Water Resour 33:468-484

Montanari A, Toth E (2007) Calibration of hydrological models in the spectral domain: an opportunity for scarcely gauged basins? Water Resour Res 43:W05434

Montanari M, Hostache R, Matgen P, Schumann G, Pfister L, Hoffmann L (2009) Calibration and sequential updating of a coupled hydrologic-hydraulic model using remote sensing-derived water stages. Hydrol Earth Syst Sci 13:367-380

Montzka C, Grant J, Moradkhani H, Hendricks-Franssen H-J, Weihermuller L, Drusch M, Vereecken H (2012) Estimation of radiative transfer parameters from SMOS brightness temperatures using data assimilation: implication on soil moisture retrieval. Vadose Zone $\mathrm{J}$ (submitted)

Moradkhani H (2008) Hydrologic remote sensing and land surface data assimilation. Sensors 8:2986-3004

Moradkhani H, Hsu K-L, Gupta H, Sorooshian S (2005a) Uncertainty assessment of hydrologic model states and parameters: sequential data assimilation using the particle filter. Water Resour Res 41:W05012. doi:10.1029/2004WR003604

Moradkhani H, Sorooshian S, Gupta HV, Houser PR (2005b) Dual state-parameter estimation of hydrological models using ensemble Kalman filter. Adv Water Resour 28:135-147

Morisette JT, Privette JL, Justice CO (2002) A framework for the validation of MODIS land products. Remote Sens Environ 83:77-96

Nagarajanar K, Judgea J, Graham WD, Monsivais-Huerteroet A (2011) Particle filter-based assimilation algorithms for improved estimation of root-zone soil moisture under dynamic vegetation conditions. Adv Water Resour 34:433-447

Nearing GS, Moran MS, Thorp KR, Collins CDH, Slack DC (2010) Likelihood parameter estimation for calibrating a soil moisture model using radar backscatter. Remote Sens Environ 115:2564-2574

Nearing GS, Crow WT, Thorp KR, Moran MS, Reichle RH, Gupta HV (2012) Assimilating remote sensing observations of leaf area index and soil moisture for wheat yield estimates: an observing system simulation experiment. Water Resour Res 48:W05525

Nichols NK (2010) Mathematical concepts of data assimilation. In: Lahoz WA, Khattatov B, Ménard R (eds) Data assimilation: making sense of observations. Springer, Berlin, pp 13-39

Ni-Meister W (2008) Recent advances on soil moisture data assimilation. Phys Geogr 29:19-37

Ni-Meister W, Houser PR, Walker J (2006) Soil moisture initialization for climate prediction: assimilation of scanning multifrequency microwave radiometer soil moisture data into a land surface model. J Geophys Res 111:1-15. doi:10.1029/2006JD007190

Njoku EG, Chan TK (2006) Vegetation and surface roughness effects on AMSR-E land observations. Remote Sens Environ 100:190-199

Noilhan J, Mahfouf J-F (1996) The ISBA land surface parameterisation scheme. Global Planet Chang 13:145-159

Norman $\mathrm{J}$ et al (2008) Simulation of $\mathrm{NO}$ and $\mathrm{N}_{2} \mathrm{O}$ emissions from a spruce forest during a freeze/thaw event using an N-flux sub-model from the PnET-N-DNDC model integrated to CoupModel. Ecol Model 216:18-30

Oki T, Kanae S (2006) Global hydrological cycles and world water resources. Science 313:1068-1072

Oleson KW et al (2010) Technical description of version 4.0 of the Community Land Model (CLM), NCAR technical note NCAR/TN-478+STR, $257 \mathrm{pp}$

Oliva R, Daganzo E, Kerr YH, Mecklenburg S, Nieto S, Richaume P, Gruhier C (2012) SMOS radio frequency interference scenario: Status and actions taken to improve the RFI environment in the 1400-1427-MHz passive band. IEEE Trans Geosci Remote Sens 50:1427-1439

Palmer TN, Doblas-Reyes FJ, Weisheimer A, Rodwell MJ (2008) Toward seamless prediction: calibration of climate change projections using seasonal forecasts. Bull Am Meteorol Soc 89:459-470 
Pan M, Wood EF (2006) Data assimilation for estimating the terrestrial water budget using a constrained ensemble Kalman filter. J Hydrometeorol 7:534-547

Pan M, Wood EF (2010) Impact of accuracy, spatial availability, and revisit time of satellite-derived surface soil moisture in a multiscale ensemble data assimilation system. J Sel Top Appl Earth Obs Remote Sens 3:49-56

Pan M, Wood EF, Wójcik R, McCabe MF (2008) Estimation of regional terrestrial water cycle using multisensor remote sensing observations and data assimilation. Remote Sens Environ 112:1282-1294

Pan M, Wood EF, McLaughlin DB, Entekhabi D, Luo L (2009) A multiscale ensemble filtering system for hydrologic data assimilation: part I, implementation and synthetic experiment. J Hydrometeorol 10:807-819

Paniconi C, Marrocu M, Putti M, Verbunt M (2003) Newtonian nudging for a Richards equation-based distributed hydrological model. Adv Water Resour 26:161-178

Parada LM, Liang X (2008) Impacts of spatial resolutions and data quality on soil moisture data assimilation. J Geophys Res 113:D10101.1-D10101.17

Parajka J, Naeimi V, Blöschl G, Wagner W, Merz R, Scipal K (2006) Assimilating scatterometer soil moisture data into conceptual hydrologic models at the regional scale. Hydrol Earth Syst Sci 10:353-368

Parinussa R, Holmes TRH, Yilmaz MT, Crow WT (2011) The impact of land surface temperature on soil moisture anomaly detection from passive microwave observations. Hydrol Earth Syst Sci 15:3135-3151

Pathmathevan M, Koike T, Lin X, Fujii H (2003) A simplified land data assimilation scheme and its application to soil moisture experiments in 2002 (SMEX02). Water Resour Res 39:SWC6.1-SWC6.20

Pauwels VRN, De Lannoy GJM (2006) Improvement of modeled soil wetness conditions and turbulent fluxes through the assimilation of observed discharge. J Hydrometeorol 7:458-477

Pauwels VRN, De Lannoy GJM (2009) Ensemble-based assimilation of discharge into rainfall-runoff models: a comparison of approaches to mapping observational information to state space. Water Resour Res 45:W08428.1-W08428.17

Pauwels VRN, Hoeben R, Verhoest NEC, De Troch FP (2001) The importance of the spatial patterns of remotely sensed soil moisture in the improvement of discharge predictions for small-scale basins through data assimilation. J Hydrol 251:88-102

Pauwels VRN, Hoeben R, Verhoest NEC, De Troch FP, Troch PA (2002) Improvement of TOPLATS-based discharge predictions through assimilation of ERS-based remotely sensed soil moisture values. Hydrol Process 16:995-1013

Pauwels VRN, Verhoest NEC, De Lannoy GJM, Defourny P, Guissard V, Lucau C (2006) Optimization of a coupled hydrology/crop growth model through the assimilation of observed soil moisture and LAI values using an Ensemble Kalman filter. Water Resour Res 43:W04421.1-W04421.17

Pauwels V, Balenzano A, Satalino G, Skriver H, Verhoest N, Mattia F (2009) Optimization of soil hydraulic model parameters using synthetic aperture radar data: An integrated multidisciplinary approach. IEEE Trans Geosci Remote Sens 47:455-457

Peischl S, Walker JP, Rüdiger C, Ye N, Kerr YH, Kim E, Bandara R, Allahmoradi M (2012a) The AACES field experiments: SMOS calibration and validation across the Murrumbidgee River catchment. Hydrol Earth Syst Sci 16:1697-1708

Peischl S, Walker JP, Ryu D, Kerr YH, Panciera R, Rüdiger C (2012b) Wheat canopy structure and surface roughness effects on multiangle observations at L-band. IEEE Trans Geosci Remote Sens 50:1498-1506

Pipunic RC, Walker J, Western A (2008) Assimilation of remotely sensed data for improved latent and sensible heat flux prediction: a comparative synthetic study. Remote Sens Environ 112:1295-1305

Plaza DA, De Keyser R, De Lannoy GJM, Giustarini L, Matgen P, Pauwels VRN (2012) The importance of parameter resampling for soil moisture data assimilation into hydrologic models using the particle filter. Hydrol Earth Syst Sci 16:375-390

Quets J, De Lannoy G, Pauwels V (2010) Analysis of spectral calibration methods for precipitationdischarge processes. Hydrol Process 24:1048-1062

Rautiainen K, Lemmetyinen J, Pulliainen J, Vehvilainen J, Drusch M, Kontu A, Kainulainen J, Seppanen J (2012) L-band radiometer observations of soil processes in boreal and subarctic environments. IEEE Trans Geosci Remote Sens 50:1483-1497

Reichle RH (2008) Data assimilation methods in the earth sciences. Adv Water Resour 31:1411-1418

Reichle RH, Koster R (2003) Assessing the impact of horizontal error correlations in background fields on soil moisture estimation. J Hydrometeorol 4:1229-1242

Reichle RH, Koster R (2004) Bias reduction in short records of satellite soil moisture. Geophys Res Lett 31:L19501.1-L19501.4 
Reichle RH, Koster R (2005) Global assimilation of satellite surface soil moisture retrievals into the NASA Catchment land surface model. Geophys Res Lett 32:L0204.1-L0204.4

Reichle RH, Entekhabi D, McLaughlin DB (2001a) Downscaling of radio brightness measurements for soil moisture estimation: a four dimensional variational data assimilation approach. Water Resour Res 37:2353-2364

Reichle RH, McLaughlin DB, Entekhabi D (2001b) Variational data assimilation of microwave radiobrightness observations for land surface hydrology applications. IEEE Trans Geosci Remote Sens 39:1708-1718

Reichle RH, McLaughlin DB, Entekhabi D (2002a) Hydrologic data assimilation with the ensemble Kalman filter. Mon Weather Rev 120:103-114

Reichle RH, Walker JP, Houser PR, Koster RD (2002b) Extended versus ensemble Kalman filtering for land data assimilation. J Hydrometeorol 3:728-740

Reichle RH, Koster R, Liu P, Mahanama SPP, Njoku EG, Owe M (2007) Comparison and assimilation of global soil moisture retrievals from the Advanced Microwave Scanning Radiometer for the Earth Observing System (AMSR-E) and the Scanning Multichannel Microwave Radiometer (SMMR). J Geophys Res 112:D09108.1-D09108.14

Reichle RH, Crow WT, Keppenne CL (2008) An adaptive ensemble Kalman filter for soil moisture data assimilation. Water Resour Res 44:W03423. doi:10.1029/2007WR006357

Reichle R, Bosilovich MG, Crow WT, Koster RD, Kumar SV, Mahanama SPP, Zaitchik BF (2009) Recent advances in land data assimilation at the NASA Global Modeling and Assimilation Office. In: Park SK, $\mathrm{Xu} \mathrm{L}$ (eds) Data assimilation for atmospheric, oceanic and hydrologic applications. Springer, New York, pp 407-428

Reichle R, Kumar SV, Mahanama SPP, Koster RD, Liu Q (2010) Assimilation of satellite derived skin temperature observations into land surface models. J Hydrometeorol 11. doi:10.1175/2010JHM1262.1

Reichle RH, Koster RD, De Lannoy GJM, Forman BA, Liu Q, Mahanama SPP, Toure A (2011) Assessment and enhancement of MERRA land surface hydrology estimates. J Clim 24:6322-6338

Reichle R, Crow W, Koster R, Kimball J, De Lannoy G (2012) SMAP Algorithm Theoretical Basis Document: L4 surface and root zone soil moisture product. Tech. Rep. SMAP Project, JPL D-66483, Jet Propulsion Laboratory, Pasadena, CA.

Reichle R, De Lannoy GJM, Forman B, Draper C, Liu Q (2013) Connecting satellite observations with water cycle variables through land data assimilation: examples using the NASA GEOS-5 LDAS. Surv Geophys (in press)

Renzullo LJ, Barrett DJ, Marks AS, Hill MJ, Guerschman JP, Mu Q, Running SW (2008) Multi-sensor model-data fusion for estimation of hydrologic and energy flux parameters. Remote Sens Environ 112:1308-1319

Rodell M, Houser P (2004) Updating a land surface model with MODIS-derived snow cover. J Hydrometeorol 5:1064-1075

Rodgers CD (2000) Inverse methods for atmospheric sounding: theory and practice. World Scientific Publishing Co. Ltd, London

Rowlandson TL, Hornbuckle BK, Bramer LM, Patton JC, Logsdon SD (2012) Comparisons of evening and morning SMOS passes over the Midwest United States. IEEE Trans Geosci Remote Sens 50:1544-1555

Roy A, Royer A, Turcotte R (2010) Improvement of springtime streamflow simulations in a boreal environment by incorporating snow-covered area derived from remote sensing data. J Hydrol 390:35-44

Rüdiger C, Albergel C, Mahfouf J-F (2010) Evaluation of the observation operator Jacobian for leaf area index data assimilation with an extended Kalman filter. J Geophys Res 118:D09111

Sabater JM, Jarlan L, Calvet J-C, Bouyssel F (2007) From near-surface to root-zone soil moisture using different assimilation techniques. J Hydrometeorol 8:194-206

Saha S, Moorthi S, Pan H-L, Wu X et al (2010) The NCEP climate forecast system re-analysis. Bull Am Metereol Soc 91:1015-1057

Sahoo A, De Lannoy GJM, Reichle RH, Houser PR (2013) Assimilation and downscaling of satellite observed soil moisture over the Little River experimental watershed in Georgia, USA. Adv Water Resour 52:19-33. doi:10.1016/j.advwatres.2012.08.007

Sanchez N, Martinez-Fernandez J, Scaini A, Perez-Gutierrez C (2012) Validation of the SMOS L2 soil moisture data in the REMEDHUS network (Spain). IEEE Trans Geosci Remote Sens 50:1602-1611

Santanello J, Peters-Lidard C, Garcia ME, Mocko DM, Tischler MA, Moran MS, Thoma DP (2007) Using remotely-sensed estimates of soil moisture to infer soil texture and hydraulic properties across a semiarid watershed. Remote Sens Environ 110:79-97

Schlenz F, dall'Amico JT, Loew A, Mauser W (2012) Uncertainty assessment of the SMOS validation in the Upper Danube catchment. IEEE Trans Geosci Remote Sens 50:1517-1529 
Schuurmans J, Troch P, Veldhuizen A, Bastiaansen W, Bierkens M (2003) Assimilation of remotely sensed latent heat flux in a distributed hydrological model. Adv Water Resour 26:151-159

Schwank M, Wigneron J-P, Lopez-Baeza E, Volksch I, Matzler C, Kerr YH (2012) L-band radiative properties of vine vegetation at the MELBEX III SMOS cal/val site. IEEE Trans Geosci Remote Sens 50:1587-1601

Scipal K, Holmes T, de Jeu R, Naeimi V, Wagner W (2008) A possible solution for the problem of estimating the error structure of global soil moisture data sets. Geophys Res Lett 35:L24403. doi: 10.1029/2008GL035599

Seneviratne SI, Corti T, Davin EL, Hirschi M, Jaeger EB, Lehner I, Orlowsky B et al (2010) Investigating soil moisture-climate interactions in a changing climate: a review. Earth Sci Rev 99:125-161

Seo D-J, Cajina L, Corby R, Howieson T (2009) Automatic state updating for operational streamflow forecasting via variational data assimilation. J Hydrol 367:255-275

Seuffert G, Wilker H, Viterbo P, Drusch M, Mahfouf J-F (2004) The usage of screen-level parameters and microwave brightness temperature for soil moisture analysis. J Hydrometeorol 5:516-531

Sherwood SC (1999) Convective precursors and predictability in the Tropical Western Pacific. Mon Weather Rev 127:2977-2991

Silvapalan M, Beven KJ, Wood EF (1987) On hydrologic similarity: 2. A scaled model of storm runoff production. Water Resour Res 23:2266-2278

Simmons AJ, Hollingsworth A (2002) Some aspects of the improvement in skill of numerical weather prediction. Q J R Meteorol Soc 128:647-677

Sini F, Boni G, Caparrini F, Entekhabi D (2008) Estimation of large-scale evaporation fields based on assimilation of remotely sensed land temperature. Water Resour Res 44:W06410

Slater AG, Clark M (2006) Snow data assimilation via an ensemble Kalman filter. J Hydrometeorol 7:478-493

Spahni R, Wania R, Neef L et al (2010) Constraining global methane emissions and uptake by ecosystems. Biogeosci Discuss 8:1643-1665

Stieglitz M, Rind D, Famiglietti J, Rosenzweig C (1997) An efficient approach to modeling the topographic control of surface hydrology for regional and global climate modeling. J Clim 10:118-137

Su H, Yang Z, Niu G, Dickinson RE (2008) Enhancing the estimation of continental-scale snow water equivalent by assimilating MODIS snow cover with the ensemble Kalman filter. J Geophys Res 113:D08120

Su H, Yang Z, Dickinson RE, Wilson CR, Niu G-Y (2010) Multisensor snow data assimilation at continental scale: the value of Gravity Recovery and Climate Experiment terrestial water storage information. J Geophys Res 115:D10104.1-D10104.14

Su H, Yang Z-L, Niu G-Y (2011) Parameter estimation in ensemble based snow data assimilation: A synthetic study. Adv Water Resour 34:407-416

Sun S, Jin J, Xue Y (1999) A simple snow-atmosphere-soil transfer (SAST) model. J Geophys Res 104:19587-19597

Sun C, Walker JP, Houser PR (2004) A methodology for snow data assimilation in a land surface model. J Geophys Res 109:D08108.1-D08108.12

Svensson M et al (2008) Bayesian calibration of a model describing carbon, water and heat fluxes for a Swedish boreal forest stand. Ecol Model 213:331-344

Taillefer F (2002) CANARI (code for the analysis necessary for arpege for its rejects and its initialization): Technical documentation, internal CNRM/GMAP report. Available from http://www.cnrm.meteo.fr/ gmapdoc/spip.php?article3

Talagrand O (2010a) Variational assimilation. In: Lahoz WA, Khattatov B, Ménard R (eds) Data assimilation: making sense of observations. Springer, Berlin, pp 41-67

Talagrand O (2010b) Evaluation of assimilation algorithms. In: Lahoz WA, Khattatov B, Ménard R (eds) Data assimilation: making sense of observations. Springer, Berlin, pp 217-240

Tapley BD, Bettadpur S, Ries JC, Thompson PF, Watkins MM (2004) GRACE measurements of mass variability in the earth system. Science 305:503-505

Tedesco M, Reichle RH, Loew A, Markus T, Foster JL (2010) Dynamic approaches for snow depth retrieval from spaceborne microwave brightness temperature. IEEE Trans Geosci Remote Sens 48:1955-1967

Trenberth KE, Fasullo J, Kiehl J (2009) Earth's global energy budget. Bull Am Meteorol Soc 90:311-323

USGEO (2010) Achieving and sustaining earth observations: a preliminary plan based on a strategic assessment by the U.S. Group on Earth Observations. Office of Science and Technology Policy, $69 \mathrm{pp}$. Available online at www.whitehouse.gov/sites/default/files/microsites/ostp/ostp-usgeo-reportearthobs.pdf

Vachon F, Goïta K, Séve DD, Royer A (2010) Inversion of a snow emission model calibrated with in situ data dor snow water equivalent monitoring. IEEE Trans Geosci Remote Sens 48:59-71 
Van den Hurk BJJ, Jia L, Jacobs C, Menenti M, Li Z-L (2002) Assimilation of land surface temperature data from ATSR in an NWP environment-a case study. Int J Remote Sens 23:5193-5209

Van den Hurk B, Ettema J, Viterbo P (2008) Analysis of soil moisture changes in europe during a single growing season in a new ECMWF soil moisture assimilation system. J Hydrometeorol 9:116-131

van Leeuwen PJ (2009) Particle filtering in geophysical systems. Mon Weather Rev 137:4089-4114

Vereecken H, Huisman JA, Bogena H, Vanderborght J, Vrugt JA, Hopmans JW (2008) On the value of soil moisture measurements in vadose zone hydrology: a review. Water Resour Res 44:W00D06

Vrugt JA, Gupta HV, Nualláin BÓ, Bouten W (2006) Real-time data assimilation for operational ensemble streamflow forecasting. J Hydrometeorol 7:548-565

Vrugt J, ter Braak C, Clark M, Hyman J, Robinson B (2008) Treatment of input uncertainty in hydrologic modeling: doing hydrology backward with Markov chain Monte Carlo simulation. Water Resour Res 44:W00B09

Vrugt J, ter Braak C, Diks C, Schoups G (2012) Advancing hydrologic data assimilation using particle markov chain monte carlo simulation: theory, concepts and applications. Adv Water Resour (anniversary issue-35 years). doi:10.1016/j.advwatres.2012.04.002

Walker JP, Houser PR (2004) Requirements of a global near-surface soil moisture satellite mission: accuracy, repeat time, and spatial resolution. Adv Water Resour 27:785-801

Walker JP, Willgoose GR, Kalma JD (2001a) One-dimensional soil moisture profile retrieval by assimilation of near-surface observations: a comparison of retrieval algorithms. Adv Water Resour 24:631-650

Walker JP, Willgoose GR, Kalma JD (2001b) One-dimensional soil moisture profile retrieval by assimilation of near-surface measurements: a simplified soil moisture model and field application. J Hydrometeorol 2:356-373

Walker JP, Willgoose GR, Kalma JD (2002) Three-dimensional soil moisture profile retrieval by assimilation of near-surface measurements: simplified Kalman filter covariance forecasting and field application. Water Resour Res 38:37.1-37.13

Wania R (2007) Modelling northern peatland land surface processes, vegetation dynamics and methane emissions. PhD thesis, University of Bristol, Bristol, $122 \mathrm{pp}$

Weerts AH, El Serafy GYH (2006) Particle filtering and ensemble Kalman filtering for state updating with hydrological conceptual rainfall-runoff models. Water Resour Res 42:W09403. doi:10.1029/2005 WR004093

Weisheimer A, Doblas-Reyes P, Jung T, Palmer T (2011) On the predictability of the extreme summer 2003 over Europe. Geophys Res Lett 38. doi:10.1029/2010GL046455

Wilker H, Drusch M, Seuffert G, Simmer C (2006) Effects of the near-surface soil moisture profile on the assimilation of L-band microwave brightness temperature. J Hydrometeorol 7:433-442

Wingeron J-P, Olioso A, Calvet J-C, Bertuzzi P (1999) Estimating root zone soil moisture from surface soil moisture data and soil-vegetation-atmosphere transfer modeling. Water Resour Res 35:3735-3745

Xu T, Liang S, Liu S (2011) Estimating turbulent fluxes through assimilation of geostationary operational environmental satellites data using ensemble kalman filter. J Geophys Res 116:621-639

Yilmaz MT, Delsole T, Houser P (2011) Improving land data assimilation performance with a water budget constraint. J Hydrometeorol 12:1040-1055

Zaitchik BF, Rodell M (2009) Forward-looking assimilation of MODIS-derived snow-covered area into a land surface model. J Hydrometeorol 10:130-148

Zaitchik BF, Rodell M, Reichle RH (2008) Assimilation of GRACE terrestrial water storage data into a land surface model: results for the Mississippi river basin. J Hydrometeorol 9:535-548

Zhan X, Houser PR, Walker JP, Crow WT (2006) A method for retrieving high-resolution surface soil moisture from Hydros L-band radiometer and radar observations. IEEE Trans Geosci Remote Sens $44: 1534-1544$

Zhang S, Shi J, Dou Y (2011) A soil moisture assimilation scheme based on the microwave land emissivity model and the community land model. Int J Remote Sens 33:2770-2797

Zupanski D (1997) A general weak constraint applicable to operational 4DVAR data assimilation systems. Mon Weather Rev 125:2274-2292 